Article

\title{
Energy and Cost Analysis of Building Envelope Components Using BIM: A Systematic Approach ${ }^{\dagger}$
}

\author{
Zoran Pučko@, Damjan Maučec and Nataša Šuman *(i) \\ Faculty of Civil Engineering, Transportation Engineering and Architecture, University of Maribor, \\ 2000 Maribor, Slovenia; zoran.pucko@um.si (Z.P.); damjan.maucec1@um.si (D.M.) \\ * Correspondence: natasa.suman@um.si; Tel.: +386-2-2294-355 \\ † This paper is an extended version: Pučko, Z.; Maučec, D.; Šuman, N. Approach to Energy and Cost Analysis of \\ External Wall Components Using BIM: Case Study of Preschool Building, 14th Conference on Sustainable \\ Development of Energy, Water and Environmental Systems, Dubrovnik, Croatia, October 1-6, 2019; \\ Publisher: Faculty of Mechanical Engineering and Naval Architecture, Zagreb, Croatia, 2019.
}

Received: 24 April 2020; Accepted: 20 May 2020; Published: 22 May 2020

check for updates

\begin{abstract}
The selection of cost-effective components of the building envelope plays a significant role in a sustainable building design solution. Therefore, in terms of effective decision-making, it is important to have a complete insight into construction and running costs throughout the lifespan of the building. A systematic building information modelling (BIM) approach as a new trend in the innovative approaches in the construction (AECO) industry provides appropriate support for improvement of environmental assessments. Our study presents a new approach to automated/semi-automated comprehensive energy and the whole life-cycle cost analysis of building envelope components using BIM, and, as such, it represents a novelty for Advanced Construction Project Management. It focuses on the sequence of steps required for evaluation of energy and economic assessment, from the basic 3D BIM model, through the energy and cost analysis, to the final evaluation and decision-making. The energy balance was calculated with dynamic simulation, the results of which formed the basis for the cost analysis. Economic assessment of construction and operating costs was performed by implementation of the cost-optimal methodology. Our proposed approach contributes to the environmental assessment of building envelope components throughout the life cycle and includes the economic valuation. The applicability of the systematic approach in our case study considered 24 different variants of building envelope components at three different U-values, namely $\mathrm{U}_{0}=0.28 \mathrm{~W} / \mathrm{m}^{2} \mathrm{~K}$ for external wall, $\mathrm{U}_{0}=0.20 \mathrm{~W} / \mathrm{m}^{2} \mathrm{~K}$ for roof, $\mathrm{U}_{1}=0.15 \mathrm{~W} / \mathrm{m}^{2} \mathrm{~K}$ and $\mathrm{U}_{2}=0.10 \mathrm{~W} / \mathrm{m}^{2} \mathrm{~K}$. Sophisticated project BIM management software was used for the economic evaluation of all elements of the life-cycle costs (LCC). In summary, the main contribution of this approach is provision of a comprehensive and simple insight into all costs in a transparent way, because a 5D BIM model allows for optimal decision-making on appropriate energy and cost-efficient envelope components.
\end{abstract}

Keywords: sustainable buildings; construction project management; BIM approach; building envelope; energy efficiency; LCC

\section{Introduction}

The sustainable development and provision of projects that actualize sustainable principles are one of the essential priorities for society's future. This is particularly crucial in construction because buildings contribute significantly to total energy consumption, which totalled 40\% in the EU in 2015 [1] and $36 \%$ of the EU's total $\mathrm{CO}_{2}$ emissions [2]. As a result, sustainable design, construction, usage and demolition can contribute significantly to the reduction of negative impacts to the environment. 
The overview of technical and scientific literature shows that the sustainable aspect of construction is mostly recognized in new buildings (residential building and public sector). Among nonresidential buildings across Europe, educational buildings represent $17 \%$, with a $12 \%$ share of total energy use [3].

The European Commission tried to reduce the final energy consumption in the residential sector by adopting the European Directive 2002/91/EC [4] on the energy performance of buildings (EPBD) and the EPBD recast [5]. The directives provided member states with the basic guidelines for defining the minimum requirements and specifications for buildings. The implementation of both directives enabled EU to reach significant efforts to increase the energy efficiency in the phase of a building design, as well as in the operational phase of the building.

Recently, many sources and studies have dealt with the sustainable planning of energy efficient envelope and its environmental impact both for residential buildings [6-11], and nonresidential buildings [12-18]. Feng et al. [6] examined the influence of certain factors, such as thermal insulation of building envelope heat transfer coefficient of a window and the ratio of window to wall, in order to determine key energy-efficient design parameters of buildings. In study [7], the authors used various insulation materials for external walls, a column, a floor and a roof to determine optimum thermal insulation thickness by considering the heating-cooling energy requirement as well as energy cost. In our case study, a comparison of four insulation materials for 20 different energy demand scenarios was made, including the implementation of the eco-efficiency analysis based on the life-cycle assessment (LCA). Furthermore, Doddo et al. [8] explored different envelope design solutions for a new multistorey building including insulation for attic roof, ground floor and exterior walls, and windows. Further, Ascione et al. [9] proposed a multiobjective optimization approach to address the envelope energy design, using a genetic algorithm to achieve the most sustainable and cost-optimal designs. In addition, Ascione et al. [10] used a multiobjective genetic algorithm to identify optimal building designs with minimal initial investment costs. Gerack and Durmuş Arsan [11], however, exemplified a decision support process that synthesized the correlation between building energy and design parameters, as well as environmental performance criteria, which can be used in the early design stages of residential buildings. On the other hand, different studies for nonresidential buildings examined the effects of energy-efficient design strategies on the building's energy performance: including, studies $[12,15,16,18]$ for office buildings, a study [13] for hotel buildings, one [14] for preschool buildings, and another [17] for industrial buildings.

Many studies were performed to identify the cost-optimal envelope energy design solution [8-10,19-21] and others minimum life-cycle cost [17,22-26], which includes the initial investment costs and the discounted running costs. Research papers $[8-10,19]$ have explored the thermal-physical properties of envelope components of new residential buildings to calculate cost-optimal performance levels. Studies [8-10,19] examined optimal thickness of thermal insulation of exterior walls, roof and ground floor and efficient windows and doors, while some have also included technical building systems [20] or, more generally, implementation of cost-benefit assessment of energy efficiency measures and their impact on improved thermal performance of building [27]. However, some studies have examined investments in energy-efficient measures by using the life-cycle costing approach [22-24]. Moreover, some researchers have focused on determining the cost-effectiveness of energy efficiency measures for nonresidential buildings: studies $[21,25,26]$ examined office buildings, while [17] investigated life cycle economics of façade systems for industrial buildings. In addition, the Graduation and Master's theses from students of civil engineering [28-30] have dealt with analysis of energy and cost efficiency of building envelopes for residential and nonresidential buildings.

Research efforts focusing on the use of building information modelling (BIM) as one of the most groundbreaking innovative approaches in the construction industry (AECO) are growing exponentially. The BIM approach addresses various aspects of combining data from different expert treatments in the form of interoperability, highlighting individual major research topics related to building energy performance, building envelope, life-cycle assessment (LCA), life-cycle cost (LCC), environmental sustainability, etc. [31,32]. Therefore, it is not surprising that some studies have already included the 
BIM approach as a support in planning the energy efficient designs for different types of buildings. Jin et al. [31] gives the current state of research in the adoption of BIM in building performance analysis (BPA) by investigating the major research areas, namely, interoperability issues in BIM enabling BPA within the context of life-cycle BPA. Further, Kamel and Memari [33] put forward challenges, issues, and shortcomings of BIM's application in building energy modelling tools and its interoperability process. Some studies have combined BIM in thermal performance of building envelope design [34-36]. Azhar et al. [34] discussed the case study of complex building performance analyses for sustainable building design using BIM, and Guo and Wei [35] implemented BIM in analysing energy consumption of the existing building to generate energy-saving effects by altering the building envelope design. Natephra et al. [36], however, used BIM to provide an automatic assessment of the overall thermal transfer values of building envelopes. The study suggested integration of BIM in the thermal transfer value calculation for the purpose of automatically extracting thermal and physical properties from the BIM database. Furthermore, some studies have focused on integrating BIM with a life-cycle assessment (LCA) and life-cycle costing (LCC) methodologies [37-39]. Santos et al. [37] examined the potential of BIM for supporting an automatic/semi-automatic environmental and economic assessment and proposed the BIM-LCA/LCC framework, while Santos et al. [38] provided a developed BIM-based environmental and economic life cycle assessment prototype tool for an automatic LCA/LCC analysis. Shadram et al. [39], however, presented a framework for supporting design decisions and enabled assessment of the embodied energy associated with the building materials supply chain. The further study by Kim et al. [40] developed a BIM-based decision-making framework for the optimization between energy efficiency and initial investment costs for decision-making purposes related to renovation. Moreover, some studies have combined BIM with sustainable building certification systems. Jrade and Jalaei [41] proposed an integrated methodology that links BIM and energy analysis tools with green building certification systems. In addition, the authors Marzouk et al. [42] combined BIM with optimization modelling and Monte-Carlo Simulation to choose the appropriate building materials that achieve minimum LCC and maximum number of credits according to green building rating system Leadership in Energy and Environmental Design (LEED). Research by Cavalliere et al. [43] proposed a novel method for applying LCA continuously over the entire building design process to assess the embodied environmental impacts by using the data provided by BIM.

Importantly, a sustainable environmental design requires buildings that are already in the early design stages to be planned as energy efficient whereby the selection criterion should be energy and cost efficiency of the building envelope components. Therefore, it is important to ensure comprehensive insight into energy performance indicators and costs that arise during the building lifetime. One of the tools for supporting implementation of construction project is building information modelling (BIM), which has great potential for advanced project management by bringing together different expertise and achieving optimal designs in 3D BIM models, by further consideration of model within various expert treatments (5D BIM for initial investment costs and 7D BIM for operational costs) and by integration of information into a comprehensive model of the building [44].

Reviewed studies treated the issue of a cost-optimal envelope energy design solution, and most of them integrated methods for assessment of energy and economic efficiency. However, only few studies included assessment procedures in implementation of the BIM approach which would support energy performance and cost analysis. The focus on integrating BIM with a cost analysis can be found in the research by Santos et al. [38], who provided the prototype tool for a completely automatic LCA and LCC analysis, by Marzouk et al. [42], who introduced the genetic algorithm optimization for simultaneous calculation of LCC and determination of the degree of the environmental sustainability using LEED-rating system, and by Kim et al. [40], who developed a decision-making framework for economic analysis of energy savings, but only discussed the investment costs in their calculation of economic feasibility.

In order to contribute to addressing the environmental assessment of building envelope components throughout the life cycle and by including the economic valuation, the present paper 
provides a new systematic approach to automated/semiautomated comprehensive energy and the whole life-cycle cost analysis of building envelope components implementing BIM. The proposed approach will fill the gap in the integration of procedures and gained results from the energy analysis, (life-cycle costs) LCC analysis, and BIM approach. This approach is based on the performed calculation of energy balance, so LCC are then calculated for each envelope component that is automated/semiautomated and connected to the so-called 5D BIM, which allows for a simple overview of all costs in the life cycle of the building, presenting a valuable scientific contribution of our research. The applicability of the proposed framework is shown on the case study of a newly erected preschool building. Energy and cost analyses were conducted in four different alternatives of external wall components and two systems of flat roofs, taking into account three different U-values. The DesignBuilder program was used for energy analysis, whereas the Vico Office (VO) program and the Cost Planner module were used for the cost analysis. The cumulative LCC is provided for all studied variants, presenting the 5D BIM modelling approach. Finally, the results and discussion for the analyses of selected variants are presented.

\section{Materials and Methods}

The strategy of choosing envelope components is crucial for the design of sustainable buildings in terms of energy efficiency for new buildings as well as for refurbishment of the existing ones. In the early design stages, decision-makers should already have information about the influence of the building envelope components on costs, in order to choose the most energy- and cost-effective variant. Therefore, a systematic approach would be reasonable and the BIM approach should be implemented as a support, where all the information from the professional treatment, gathered in one place, forms the basis for an optimal decision-making. Such an approach represents advanced construction project management, which is the main contribution of the paper.

Figure 1 shows the suggested systematic approach. After definition of goals, assumptions, and restrictions for the subjected building, the process of energy and cost analysis begins with the definition of the chosen variants. More specifically, assumptions are defined in order to choose variants of structural systems of envelope components and levels of U-values which will be analysed; and the restrictions are noted for the chosen structural and heating, ventilation and air conditioning (HVAC) systems. In the first step, the basic 3D BIM is modelled in appropriate programs, such as ArchiCad, Revit, Tekla Structure, etc. The basic model is then adapted to all chosen variants. This is followed by energy analysis of selected variants in a program, such as DesignBuilder, PHPP, EcoDesigner STAR or similar. Here, the energy balance of the building is modelled, and final energy for heating and cooling is calculated separately for each selected level of U-values. Next, the cost analysis is performed in suitable programs, e.g., Vico Office, iTWO, MS Excel, or similar. The life-cycle costs (LCC) approach is applied for all variants including the initial investment cost, maintenance and operation (O\&M) costs, and the residual value of envelope components. The results of economic evaluated elements of LCC are then combined and transferred into the proper BIM project management software. The automatic update of recalculation of the LCC elements can be provided in this program, which is based on mutual interconnected information. Based on the gained results, the investor can make the right decision about the most energy- and cost-effective variant.

\subsection{Modelling 3D BIM}

A modern BIM approach enables the digitalization of construction projects with parametric modelling, which provides, in addition to geometric information and visualization, information collection of all used materials for element components with their properties. Furthermore, it enables the modelling of processes during the entire life cycle of a building in the most automated possible way. Already in the design phase, the goal is to create a comprehensive BIM model bringing together the data of all project participants, which represents a digital model of a future building. BIM brings many advantages, but also changes to current construction practice. In the design phase, the basic 3D BIM model of the building is first modelled, resulting in an architectural design together with the 
geometry of the building. It continues with a variety of professional operations where variant analyses, simulations, logistical conflicts, clash detections, virtual building animations and other actions are performed, without major additional costs and time. In general, an understanding of the terms level of BIM maturity [45] and level of development (LOD) [46] are important for BIM approach. Improvement of the BIM model within the LOD level and other detailed information increase with the development of project documentation and a project in general. The BIM approach also offers various dimensions of BIM models by upgrading information, taking into account the methodology of professional treatment of a construction project [47]. For example, a 3D BIM model upgraded with the construction schedule provides the 4D BIM model, while the upgrade with estimated construction costs leads to the 5D BIM model, which may also include running costs in the building life cycle [48].

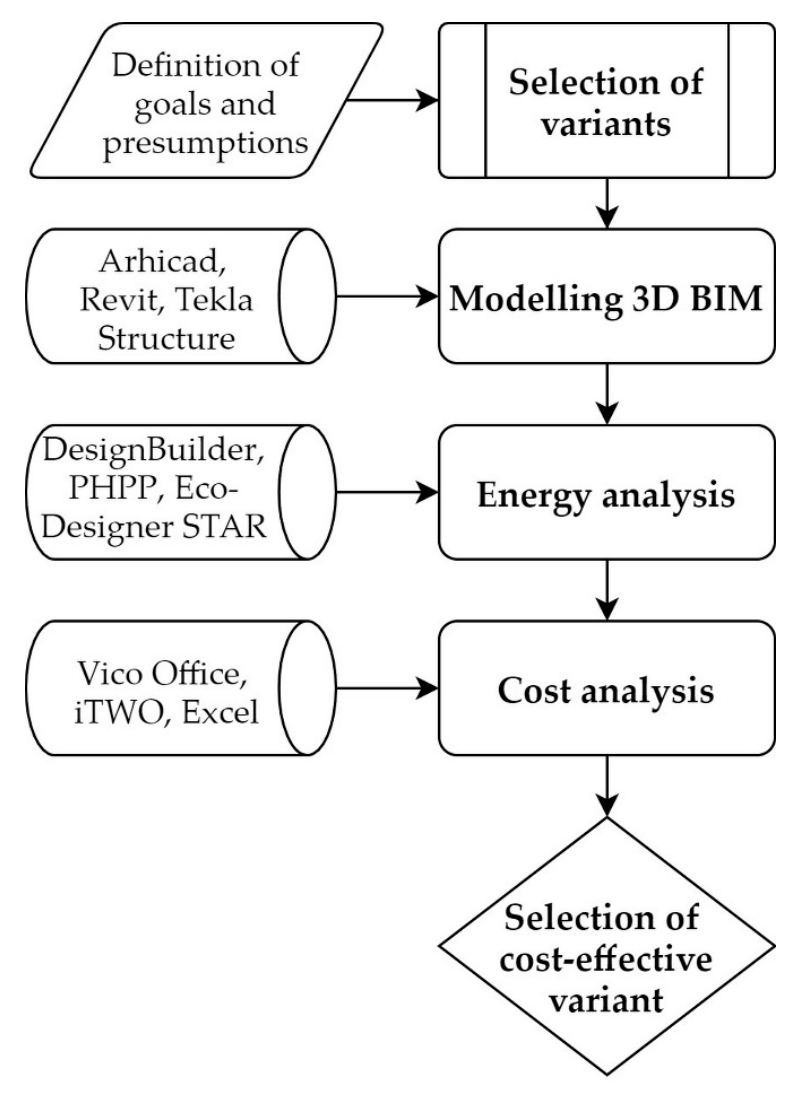

Figure 1. A systematic approach for energy and cost analysis of the building envelope components using building information modelling (BIM).

\subsection{Energy Analysis}

The energy efficiency of the building is the amount of energy required for its normal operation, including the heating $\left(Q_{h}\right)$, cooling $\left(Q_{c}\right)$, and ventilation demands $\left(Q_{v}\right)$ in addition to hot water supply and lighting energy consumption. The energy balance of the building generally consists of the transmission heat losses $\left(Q_{t}\right)$, ventilation heat losses $\left(Q_{v}\right)$, internal heat gains $\left(Q_{i}\right)$, and solar heat gains $\left(Q_{s}\right)$, given in the form of Equation (1) [14].

$$
\begin{aligned}
Q_{t}+Q_{v}+\left(Q_{i}+Q_{s}\right)=\Delta Q & =Q_{h} \ldots \text { in heating period } \\
& =Q_{c} \ldots \text { in cooling period }
\end{aligned}
$$

The energy assessment can be conducted by means of the dynamic simulation software, such as DesignBuilder, PHPP, EnergyPlus. It calculates energy balance as a simulation of the energy behaviour of several solutions for building envelope components and evaluates annual heating and cooling needs of the building. 


\subsection{Cost Analysis}

Above all, the cost efficiency is the most important for the investor when deciding about the energy efficiency measures in new buildings. The principle of lifetime costs is used for the economic assessment of designed building envelope variants. Namely, the life cycle cost (LCC) methodological approach $[22,25,49]$ is based on the logic that economically optimal design solutions minimize the sum of construction and operating expenses over the building lifetime. In doing so, the estimation of expected costs depends on the performed calculation of energy balance. Thus, for each variant, the economic assessment is performed through their net present value (NPV), and, for this purpose, cost-optimal methodology (according to the methodological framework of the European Regulation 244/2012/EU [50]) was used [51]. Calculation of NPV was based on the following expression of building envelope components $j$.

$$
C_{j}+\sum_{j}\left[\sum_{j}\left(C_{a, i}(j) \times R_{d}(i)\right)-V_{f, \tau}(j)\right]
$$

where, $C_{j}$ is the initial investment cost; $C_{a, i}(j)$ are the net annual costs for variant of building envelope components $j$ at year $i$ (including operation costs, maintenance costs and replacement costs); $V_{f, \tau}$ is the residual value of the variant of building envelope components $j$ at the end of the calculation period; $R_{d}$ is the discount factor for year $i$ based on the discount rate $r$.

$$
R_{d}(i)=\left(\frac{1}{1+\frac{r}{100}}\right)^{i}
$$

\section{Case Study}

The applicability of the addressed BIM-based systematic approach for automated/semiautomated comprehensive energy and cost analysis of building envelope components is supported here by the case study of a newly erected preschool building in the city of Maribor for four different alternatives of external wall components and two systems of flat roof, taking into account three different $\mathrm{U}$-values.

\subsection{Description of the Building}

The preschool building is an "L" shape with dimensions $11.10 \mathrm{~m} \times 17.10 \mathrm{~m}$ and $21.60 \mathrm{~m} \times 9.90 \mathrm{~m}$. The height of the building is $9.47 \mathrm{~m}$ (upper part) and $9.17 \mathrm{~m}$ (lower part); it has two floors. The building has a gross area of $797.40 \mathrm{~m}^{2}$. It is functionally designed with three playrooms and a room for additional activities (which can be converted into a playroom) and has a capacity for 66 children, providing employment for 10 people [29,52]. The main entrance is at the east of the building, while the accesses to the wardrobe and the kitchen are on the south. The playrooms are on the south side of the building, from which are accesses to the terrace. The geolocation of the preschool building is in the local community Pekre, near the city of Maribor, which was taken into account in the energy analysis in terms of the orientation of the building.

Structurally, the building is designed with brick walls (Porotherm $30 \mathrm{~S}$ Plus) and the slabs (above the ground floor and the first floor) are made of reinforced concrete. The foundation is also made of reinforced concrete and the floor structures against the terrain are made on a compacted, filled-up ground, with waterproofing strips, $10 \mathrm{~cm}$ of thermal insulation, concrete screed, and a top layer. The exterior walls are made of $30 \mathrm{~cm}$-thick bricks, the internal bearing walls are $20 \mathrm{~cm}$ thick bricks and internal non-load-bearing walls are a dry-assembly version. Reinforced concrete bonds are made between the brick walls, generally every three meters. Above the ground floor slab, a floor structure is applied with appropriate finishing layers.

The façade of the building is a thermal insulating contact façade with façade insolation board and is constructed in the Baumit open system. The roof is nonwalkable and flat, with the following finishing layers: multilayer waterproofing strips, polyethylene (PE) foil, roof insulation board in the 
upper part of the slope, vapour-permeable foil, a layer of felt, and a layer of gravel. All windows are wooden with thermal insulating glass $\left(\mathrm{U}_{\mathrm{g}}=0.60 \mathrm{~W} /\left(\mathrm{m}^{2} \mathrm{~K}\right), \mathrm{U}_{\mathrm{f}}=1.01 \mathrm{~W} /\left(\mathrm{m}^{2} \mathrm{~K}\right), \Psi=0.04 \mathrm{~W} /(\mathrm{mK})\right.$, $\mathrm{g}=0.50)$. The entrance doors are made of aluminium with thermal insulating glass and the interior doors are wooden (wing and lintel) and partly glazed with safety glass. The floor in the playrooms is finished parquet with floor heating; in other spaces there are ceramics and flooring in epoxy mortar and rubber. The inner wall surfaces are plastered and ground, tinted and dyed.

The rooms in the building are heated with a floor heating system and cooled with air conditioning. Heating and hot water is provided by a heat pump (air-water). The boiler room is located on the ground floor on the east side. The building is ventilated mechanically with a central heat-recovery ventilation system $[29,52]$.

\subsection{Building Modelling with BIM Approach}

Archicad software, as one of the tools for building modelling using BIM, was used to create the basic 3D model of the preschool building. An important advantage of the modern BIM approach lies in enabling parametric modelling, which, besides the geometric information and visualization, provides information collection for all materials used for element components as well as their properties. As a result, all information is gathered in one place and displayed in the comprehensive 3D BIM, as shown in Figure 2.

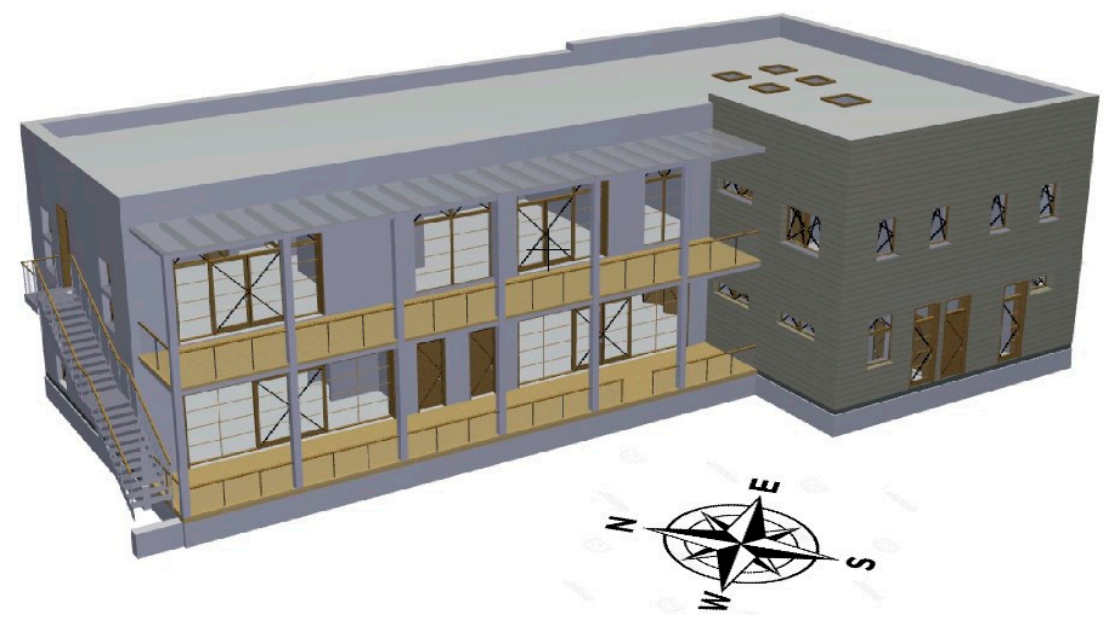

Figure 2. Display of the new preschool building in a comprehensive 3D BIM (C) 2020, IGI Global, www.igi-global.com [44]. Used with permission.

The obtained 3D BIM is useful for many expert treatments, such as providing energy and cost analysis in our case study, where the wall components of the building envelope are changed for different variants, and the designed 3D BIM serves as a base for energy and cost analysis.

\subsection{Description of Analysed Envelope Components and Combinations}

Our case study for the new preschool building compares external bearing walls and flat roof for three different $U$-values, namely $U_{0}, U_{1}$ and $U_{2} . U_{0}$ represents minimum standard according to the Slovenian regulation [53] for external wall $\mathrm{U}_{0}=0.28 \mathrm{~W} / \mathrm{m}^{2} \mathrm{~K}$ and for roof $\mathrm{U}_{0}=0.20 \mathrm{~W} / \mathrm{m}^{2} \mathrm{~K}$. $\mathrm{U}_{1}$ represents a low energy standard where $\mathrm{U}_{1}=0.15 \mathrm{~W} / \mathrm{m}^{2} \mathrm{~K}$ is considered for both elements, and $\mathrm{U}_{2}$ is the representative for the passive house standard considering $U_{2}=0.10 \mathrm{~W} / \mathrm{m}^{2} \mathrm{~K}$.

Two structural systems are considered for the external wall: three alternatives of a brick system: Porotherm 30 PROFI-B30P [54], Porotherm 32 IZO PROFI-B32I [55], and Porotherm 30 S Plus-B30S [56], and one alternative for a reinforced concrete system $(R C 20 \mathrm{~cm})-W R C$. Two systems of roofing are considered for the flat roof with reinforced concrete slab construction: one with multilayer 
waterproofing strips-FRC1 and one with polymeric waterproofing membrane for a mechanically fixed roof-FRC2.

Analysing energy and cost efficiency, different $U$-values were selected both for the external wall and roof systems; the combination of wall and roof systems has defined eight solutions for each level of thermal transmittance of the whole building, which means that the total analysis was performed for 24 different combinations. Detailed descriptions and comparison of analysed variants of the individual systems of external walls and roof components are given in Tables 1 and 2.

The following assumptions are considered in the calculation of energy and cost analysis:

- The calculations of U-values of each variant consider real dimensions of deliverable thickness of the thermal isolation, where defined or better border limits are regarded;

- The principles for the outer side and inside of external walls and a roof are similar;

- The difference of the outer side of both elements is only in the thickness of the used thermal isolation according to three different defined U-values;

- Other key elements of building envelope do not change;

- Data on thermal conductivity for the internal finish plaster, RC wall, RC roof slab, the façade finishing system (external wall plaster), and roofing (PE foil, gravel, vapor permeable foil, waterproofing) are taken from the Technical guidelines TSG-1-004 Efficient use of energy [53];

- Data on thermal conductivity for brick blocks are taken from their declaration of performance and technical data of manufacturer [54-56];

- Structural design and systems of structural elements take into consideration the established design documentation [52].

\subsection{Calculation of the Energy Balance}

The amount of energy required for heating $\left(Q_{h}\right)$ in heating period and for cooling demand $\left(Q_{c}\right)$ needed in the summer period is evaluated with the calculation of energy balance. The calculations are performed with the software DesignBuilder 4.5 [57]. The calculation of energy analysis considers the following input data and assumptions:

- Occupancy of the premises: people $100 \%$;

- Minimum indoor temperature in heating period $22^{\circ} \mathrm{C}$;

- Maximal indoor temperature in cooling period $25^{\circ} \mathrm{C}$;

- Internal gains $Q_{i}=2.8 \mathrm{~W} / \mathrm{m}^{2}$;

- Net heated floor area $A_{h}=695.68 \mathrm{~m}^{2}$ and net heated volume $V_{h}=2644.00 \mathrm{~m}^{3}$, internal height (for each floor) $H_{h}=3.80 \mathrm{~m}$;

- Glazing-to-wall area ratio (AGAW): $\mathrm{AGAW}_{\text {south }}=33.0 \%, \mathrm{AGAW}_{\text {north }}=24.4 \%, \mathrm{AGAW}_{\text {west }}=1.3 \%$, AGAW $_{\text {east }}=22.5 \%$;

- Ventilation unit with heat recovery: heat recovery efficiency $\eta=82 \%$, electric efficiency $0.41 \mathrm{Wh} / \mathrm{m}^{3}$ (according to technical characteristics for the ventilation unit by manufacturer PICHLER type LG 3200 [58], with certificate by Passive House Institute (PHI) [59];

- Air change rate at press. test (air test of $50 \mathrm{~Pa}) n_{50}=0.60 \mathrm{~h}^{-1}$ (according to PHI [59]);

- Relative humidity (RH) humidification setpoint: $10 \%$ and RH dehumidification setpoint: $90 \%$;

- Minimum average sum of natural, mechanical, and infiltration air change rate according to [60]: $0.5 \mathrm{~h}^{-1}$; average air change rate with natural and mechanical ventilation together with infiltration is $0.87 \mathrm{~h}^{-1}$. 
Table 1. The comparison of the analysed external wall components.

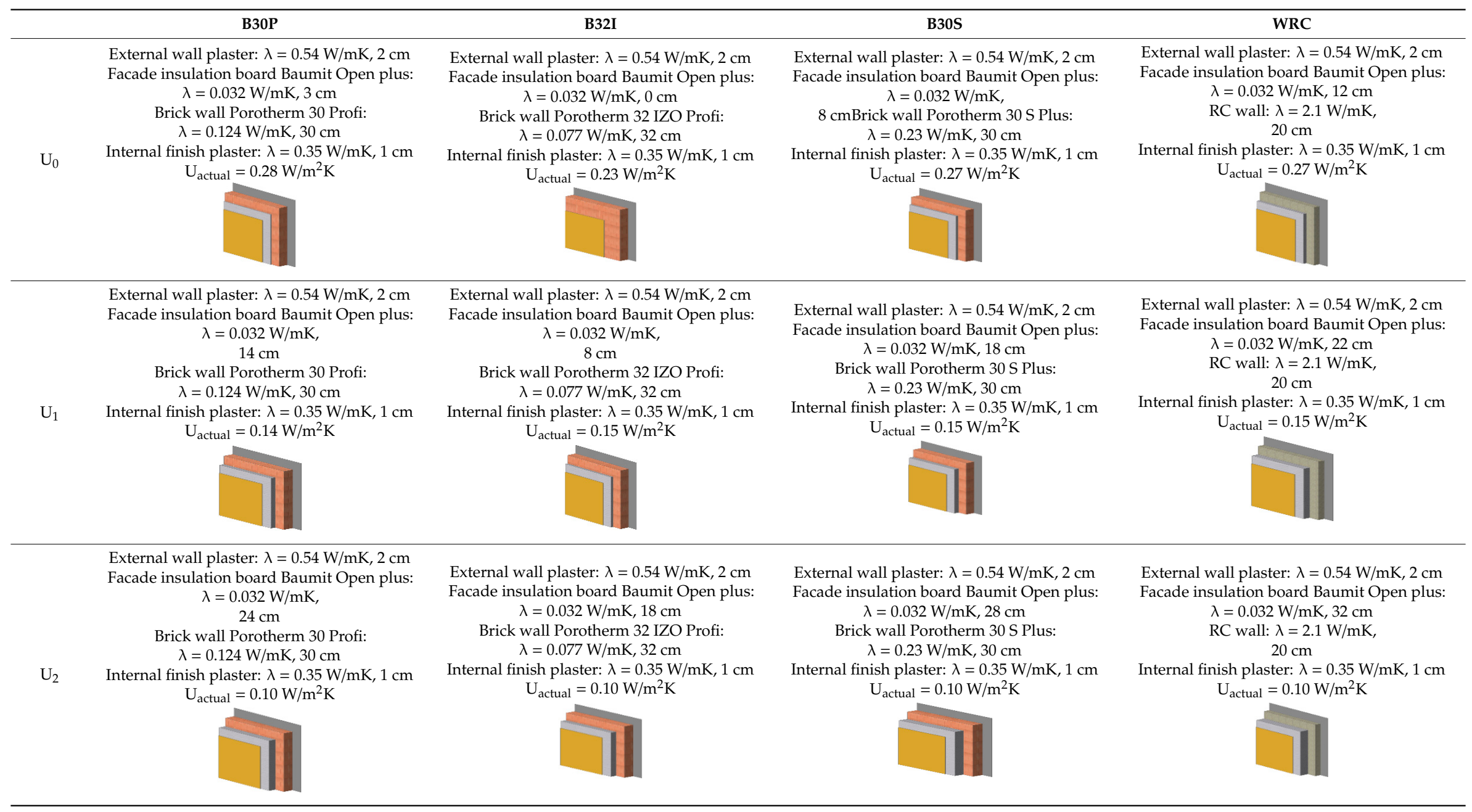


Table 2. The comparison of the analysed roof components.

\begin{tabular}{|c|c|c|}
\hline & FRC1 & FRC2 \\
\hline $\mathrm{U}_{0}$ & $\begin{array}{c}\text { Gypsum fibreboard } \lambda=0.21 \mathrm{~W} / \mathrm{mK}, 1.25 \mathrm{~cm} \\
\text { RC slab: } \lambda=2.1 \mathrm{~W} / \mathrm{mK}, 24 \mathrm{~cm} \\
\text { Multilayer waterproofing strips: } \lambda=0.19 \mathrm{~W} / \mathrm{mK}, \\
1 \mathrm{~cm} \text {, polyethylene }(\mathrm{PE}) \text { foil } \\
\text { Roof insulation board XPS: } \lambda=0.036 \mathrm{~W} / \mathrm{mK}, \\
12 \mathrm{~cm}+\lambda=0.033 \mathrm{~W} / \mathrm{mK}, 4 \mathrm{~cm} \\
\text { Vapor permeable foil } \\
\text { Layer of felt } \\
\text { Layer of gravel: } \lambda=0.36 \mathrm{~W} / \mathrm{mK}, 8 \mathrm{~cm} \\
\text { Uactual }^{=}=0.19 \mathrm{~W} / \mathrm{m}^{2} \mathrm{~K}\end{array}$ & $\begin{array}{c}\text { Gypsum fibreboard } \lambda=0.21 \mathrm{~W} / \mathrm{mK}, 1.25 \mathrm{~cm} \\
\text { RC slab: } \lambda=2.1 \mathrm{~W} / \mathrm{mK}, 24 \mathrm{~cm} \\
\text { Vapor barrier } \\
\text { Roof insulation board SmartRoof: } \lambda=0.038 \mathrm{~W} / \mathrm{mK}, 14 \mathrm{~cm}+4 \mathrm{~cm} \\
\text { Layer of feltPolymeric waterproofing membrane: SikaplanSG } \\
\text { Layer of felt } \\
\text { Layer of gravel: } \lambda=0.36 \mathrm{~W} / \mathrm{mK}, 8 \mathrm{~cm} \\
\mathrm{U}_{\text {actual }}=0.20 \mathrm{~W} / \mathrm{m}^{2} \mathrm{~K}\end{array}$ \\
\hline $\mathrm{U}_{1}$ & $\begin{array}{c}\text { Gypsum fibreboard } \lambda=0.21 \mathrm{~W} / \mathrm{mK}, 1.25 \mathrm{~cm} \\
\text { RC slab: } \lambda=2.1 \mathrm{~W} / \mathrm{mK}, 24 \mathrm{~cm} \\
\text { Multilayer waterproofing strips: } \lambda=0.19 \mathrm{~W} / \mathrm{mK} \\
1 \mathrm{~cm} \text {, polyethylene }(\mathrm{PE}) \text { foil } \\
\text { Roof insulation board XPS: } \lambda=0.036 \mathrm{~W} / \mathrm{mK} \\
12 \mathrm{~cm}+\lambda=0.035 \mathrm{~W} / \mathrm{mK}, 10 \mathrm{~cm} \\
\text { Vapor permeable foilLayer of felt } \\
\text { Layer of gravel: } \lambda=0.36 \mathrm{~W} / \mathrm{mK}, 8 \mathrm{~cm} \\
U_{\text {actual }}=0.15 \mathrm{~W} / \mathrm{m}^{2} \mathrm{~K}\end{array}$ & $\begin{array}{c}\text { Gypsum fibreboard } \lambda=0.21 \mathrm{~W} / \mathrm{mK}, 1.25 \mathrm{~cm} \\
\text { RC slab: } \lambda=2.1 \mathrm{~W} / \mathrm{mK}, 24 \mathrm{~cm} \\
\text { Vapor barrier } \\
\text { Roof insulation board SmartRoof: } \lambda=0.038 \mathrm{~W} / \mathrm{mK}, 14 \mathrm{~cm}+10 \mathrm{~cm} \\
\text { Layer of felt } \\
\text { Polymeric waterproofing membrane: SikaplanSG } \\
\text { Layer of felt } \\
\text { Layer of gravel: } \lambda=0.36 \mathrm{~W} / \mathrm{mK}, 8 \mathrm{~cm} \\
\mathrm{U}_{\text {actual }}=0.15 \mathrm{~W} / \mathrm{m}^{2} \mathrm{~K} \\
\end{array}$ \\
\hline $\mathrm{U}_{2}$ & $\begin{array}{c}\text { Gypsum fibreboard } \lambda=0.21 \mathrm{~W} / \mathrm{mK}, 1.25 \mathrm{~cm} \\
\text { RC slab: } \lambda=2.1 \mathrm{~W} / \mathrm{mK}, 24 \mathrm{~cm} \\
\text { Multilayer waterproofing strips: } \lambda=0.19 \mathrm{~W} / \mathrm{mK} \\
1 \mathrm{~cm} \text {, polyethylene (PE) foil } \\
\text { Vapor permeable foil } \\
\text { Layer of felt } \\
\text { Roof insulation board XPS: } \lambda=0.036 \mathrm{~W} / \mathrm{mK}, 2 \times 12 \mathrm{~cm}+\mathrm{W} / \mathrm{mK}, 10 \mathrm{~cm} \\
\text { Layer of gravel: } \lambda=0.36 \mathrm{~W} / \mathrm{mK}, 8 \mathrm{~cm} \\
\mathrm{U}_{\text {actual }}=0.10 \mathrm{~W} / \mathrm{m}^{2} \mathrm{~K}\end{array}$ & $\begin{array}{c}\text { Gypsum fibreboard } \lambda=0.21 \mathrm{~W} / \mathrm{mK}, 1.25 \mathrm{~cm} \\
\text { RC slab: } \lambda=2.1 \mathrm{~W} / \mathrm{mK}, 24 \mathrm{~cm} \\
\text { Vapor barrier } \\
\text { Roof insulation board SmartRoof: } \lambda=0.038 \mathrm{~W} / \mathrm{mK}, 14 \mathrm{~cm}+14 \mathrm{~cm}+10 \mathrm{~cm} \\
\text { Layer of feltPolymeric waterproofing membrane: SikaplanSG } \\
\text { Layer of felt } \\
\text { Layer of gravel: } \lambda=0.36 \mathrm{~W} / \mathrm{mK}, 8 \mathrm{~cm} \\
\text { Uactual }=0.10 \mathrm{~W} / \mathrm{m}^{2} \mathrm{~K}\end{array}$ \\
\hline
\end{tabular}


The amount of energy required for heating $\left(Q_{h}\right)$ in heating period and for cooling demand $\left(Q_{c}\right)$ needed in the summer period is evaluated with the calculation of energy balance. The calculations are performed with the software DesignBuilder (Version 4.5, DesignBuilder Software Ltd., London Rd., Stroud, UK) [57]. Results of the calculation of energy analysis for defined variants are given in Table 3.

Table 3. Result of energy balance for defined variants.

\begin{tabular}{|c|c|c|c|c|c|c|c|c|c|c|c|c|}
\hline \multirow[b]{2}{*}{$\left(\mathrm{kWh} / \mathrm{m}^{2} \mathrm{a}\right)$} & \multicolumn{4}{|c|}{$\mathrm{U}_{0}$} & \multicolumn{4}{|c|}{$\mathrm{U}_{1}$} & \multicolumn{4}{|c|}{$\mathbf{U}_{2}$} \\
\hline & $\begin{array}{l}\mathrm{B} 30 \mathrm{P}+ \\
\text { FRC1 }\end{array}$ & $\begin{array}{l}\text { B32I + } \\
\text { FRC1 }\end{array}$ & $\begin{array}{l}\text { B30S + } \\
\text { FRC1 }\end{array}$ & $\begin{array}{l}\text { WRC + } \\
\text { FRC1 }\end{array}$ & $\begin{array}{l}\mathrm{B} 30 \mathrm{P}+ \\
\text { FRC1 }\end{array}$ & $\begin{array}{l}\text { B32I + } \\
\text { FRC1 }\end{array}$ & $\begin{array}{l}\text { B30S + } \\
\text { FRC1 }\end{array}$ & $\begin{array}{l}\text { WRC + } \\
\text { FRC1 }\end{array}$ & $\begin{array}{l}\mathrm{B} 30 \mathrm{P}+ \\
\text { FRC1 }\end{array}$ & $\begin{array}{l}\text { B32I + } \\
\text { FRC1 }\end{array}$ & $\begin{array}{l}\text { B30S + } \\
\text { FRC1 }\end{array}$ & $\begin{array}{c}\text { WRC + } \\
\text { FRC1 }\end{array}$ \\
\hline$Q_{h}$ & 41.05 & 37.09 & 38.64 & 38.44 & 28.50 & 28.72 & 28.30 & 28.24 & 23.22 & 23.32 & 23.13 & 23.10 \\
\hline$Q_{c}$ & 3.96 & 3.94 & 3.95 & 3.95 & 3.85 & 3.85 & 3.85 & 3.85 & 3.78 & 3.78 & 3.78 & 3.78 \\
\hline$Q_{h+c}$ & 45.01 & 41.03 & 42.58 & 42.39 & 32.35 & 32.57 & 32.15 & 32.10 & 27.00 & 27.10 & 26.91 & 26.88 \\
\hline$\left(\mathrm{kWh} / \mathrm{m}^{2} \mathrm{a}\right)$ & $\begin{array}{l}\text { B30P + } \\
\text { FRC2 }\end{array}$ & $\begin{array}{l}\text { B32I + } \\
\text { FRC2 }\end{array}$ & $\begin{array}{l}\text { B30S + } \\
\text { FRC2 }\end{array}$ & $\begin{array}{l}\text { WRC + } \\
\text { FRC2 }\end{array}$ & $\begin{array}{l}\text { B30P + } \\
\text { FRC2 }\end{array}$ & $\begin{array}{l}\text { B32I + } \\
\text { FRC2 }\end{array}$ & $\begin{array}{l}\text { B30S + } \\
\text { FRC2 }\end{array}$ & $\begin{array}{l}\text { WRC + } \\
\text { FRC2 }\end{array}$ & $\begin{array}{l}\text { B30P + } \\
\text { FRC2 }\end{array}$ & $\begin{array}{l}\text { B32I + } \\
\text { FRC2 }\end{array}$ & $\begin{array}{l}\text { B30S + } \\
\text { FRC2 }\end{array}$ & $\begin{array}{c}\text { WRC + } \\
\text { FRC2 }\end{array}$ \\
\hline$Q_{h}$ & 41.05 & 37.10 & 38.64 & 38.45 & 28.56 & 28.78 & 28.36 & 28.30 & 23.10 & 23.20 & 23.01 & 22.98 \\
\hline$Q_{c}$ & 3.96 & 3.94 & 3.95 & 3.95 & 3.85 & 3.85 & 3.85 & 3.85 & 3.78 & 3.78 & 3.78 & 3.78 \\
\hline$\widetilde{Q_{h+c}}$ & 45.01 & 41.04 & 42.59 & 42.39 & 32.41 & 32.63 & 32.21 & 32.15 & 26.88 & 26.98 & 26.79 & 26.76 \\
\hline
\end{tabular}

\subsection{Cost Analysis}

The proposed approach includes cost analysis within the LCC approach, wherein costs are divided into initial investment costs, operation and maintenance (O\&M) costs, and the residual value of envelope components. The first involves all the costs for planning, design, and acquisition (including preconstruction and construction) of the building envelope components (external walls and the roof); the second includes costs for operation and maintenance from the start of operation to the completion of the study period of the building and takes into account the residual value of the elements.

In terms of economic assessment, the following characteristics of costs and residual value are considered:

1. Initial investment costs: in general, these costs include costs for activities of preconstruction phases and costs for construction of the building. In our case study, only costs for erecting all components of external walls and the flat roof are regarded. Therefore, these costs are calculated according to the principle of the unit price for all items needed to complete the whole component. Calculations of a unit price are based on predefined construction technology and geometric characteristics of the element. They utilize the norms for construction (masonry, reinforced concrete works, formworks, plaster) and craft works (façade and painting works) [54-56,61,62], and the average price of labour [63] and market price of materials per unit of measure [62-68]. Prices for some items are given according to the average market prices; all without VAT. Figure 3a) shows the initial investment costs per square meter of net heated floor area $\left(A_{h}\right)$ for all variants. Costs for all preconstruction phases and construction of other building components as well as costs for installing window and door lintels are not analysed because we assume that they are the same in all variants. We also made preliminary calculations for all initial investment costs of construction (including construction, craft and installation works) for the basic variant of the building (as described in the chapter 3.1) and it does not include the values for the external wall and flat roof systems, totalling $665,504.42 €[69]$.

2. O\&M costs: In general, these are annual running costs throughout the lifespan of the building divided into a) maintenance costs as total of incurred labour, material, and other related costs to maintain the building or its parts in an adequate state to perform its required functions; and b) operation costs that include running costs and costs of the facility management, involving administrative support services (e.g., rent, rates, insurances, energy, and other environmental/regulatory inspection costs, local taxes and charges) [49]. Our case study considers maintenance costs as the costs that are required to keep the utility and the value of the walls and a roof, namely, façade components for the wall and upper layers of the roofing for a flat roof. Maintenance tasks for the normal service life of the façade include regular repairs of mechanically 
damaged plaster, and regular maintenance of hanging gutters, roof drain pipes, and window sills (washing and cleaning to prevent soaking and dirt of the facade) while the tasks for roof maintenance include regular maintenance and inspections, cleaning of drainage shafts on the roof, and regular care prevent mechanical damage to the insulation (e.g., during new interventions). Maintenance costs also include the replacement of individual worn-out elements after the end of their service life. Further, energy costs for space heating and cooling are taken into account as operating costs. Figure $3 b$ ) shows the O\&M costs per square meter of net heated floor area $\left(A_{h}\right)$ for all variants. The calculation of O\&M cost considers the following assumptions:

- Maintenance costs include regular maintenance of a lesser value and maintenance cost, which is taken into account only for the elements for which service life expires in the relevant study period and which are intended for reimplementation;

- Maintenance costs are evaluated against the linear function for physical deterioration of the building element's condition;

- Values of regular maintenance are summarized by national rules [70] and represent the fraction of small repairs (in \%) to new value;

- The service life for the façade and roofing in the variant FRC1 is summarized by national rules [70], namely, for façade 40 and for the roofing, 20 years, and, for roofing in the variant FRC2, by the product declaration for the waterproofing membrane [71] which specifies 30 years;

- The reimplementation of the element in the 20 years is considered for variants of combinations with roofing FRC1 while the component has a shorter service life as a study period. To simplify the presentation of costs on an annual basis, they are spread over all years of the study period;

- Building annual energy end use for the conditioned floor area is for all treated variants provided by whole building energy simulations run in DesignBuilder 4.5 [57] through its simulation module;

- Annual energy costs are provided via estimation of future energy costs based on utility rates for electricity;

- Utility rates for electricity are obtained from the building operator, totalling $0.138 € / \mathrm{kWh}$, and representing the increased cost in $\mathrm{kWh}$ (including taxes and charges) of electricity consumption in 2018, which was the first year of the full operation;

- The annual increase of maintenance costs and energy price forecasts are embodied in the discounting of maintenance and electricity costs over the study period;

- Other maintenance costs and operating costs (such as insurance, local taxes, and local charges) are neglected because they do not play any important role in the relation to the energy costs and they are the same for all variants and thus have no influence on decision-making.

When estimating O\&M cost, it is also necessary to understand the impacts of economic and other parameters that significantly affect these costs. Economic parameters consist of discount rate, life-cycle period and capital costs, whereas other parameters that refer to each component include, e.g., estimated service life and unit costs for energy, labor, materials, and others. However, the effects of changes in these parameters are excluded in our study.

3. Residual value: the residual value of the building represents the value of an asset at the end of its service life. It is the amount of value that the owner can expect to obtain when the asset is dispositioned. In our case study, the amount of residual value is calculated taking into account the carrying amount of the value. Therefore, it represents the carrying amount from the construction of all components of the façade and roofing (excluding VAT) at the end of the building study period. For individual components, it is derived from the difference between the initial investment value and the value of component at the end of the study period of the building (i.e., 30 years in our case study). Therefore, the carrying amount for components of which service 
life is longer than the study period, e.g., the façade, is considered as the difference between the investment value and the value after 30 years. The carrying amount of components whose service life is shorter is considered as the difference between the investment value of element reinstallation (by the end of its service life) and the value of this element at the conclusion of the study period of the building. For example, the residual value of the roofing for the variant FRC1 with a 20-year service life is, after 30 years, the same as the difference between the investment value for reinstallation of the roof and its value after 10 years (the study period of the building is then accomplished). Considering the service life of roofing elements for the variant FRC2, residual value is zero because service life equals study period (see Figure $3 c$ ).

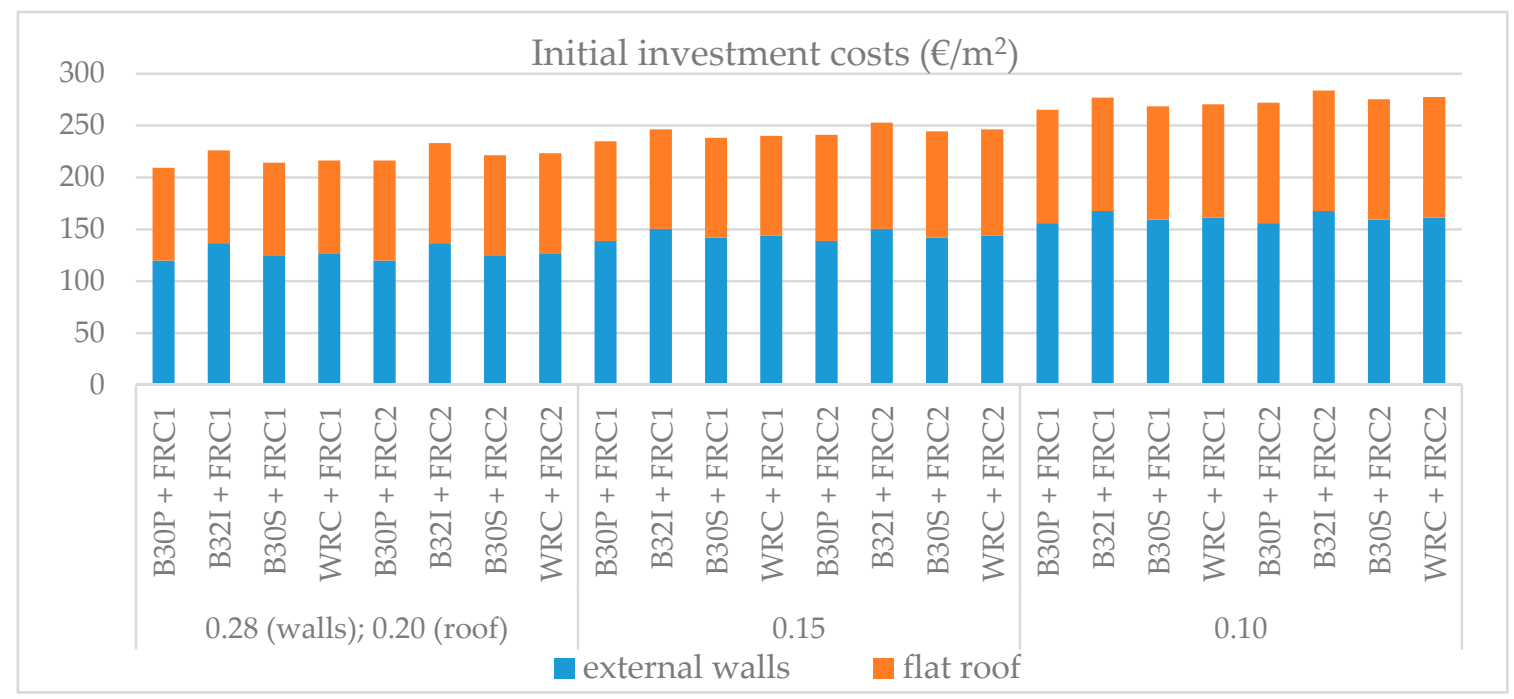

(a)

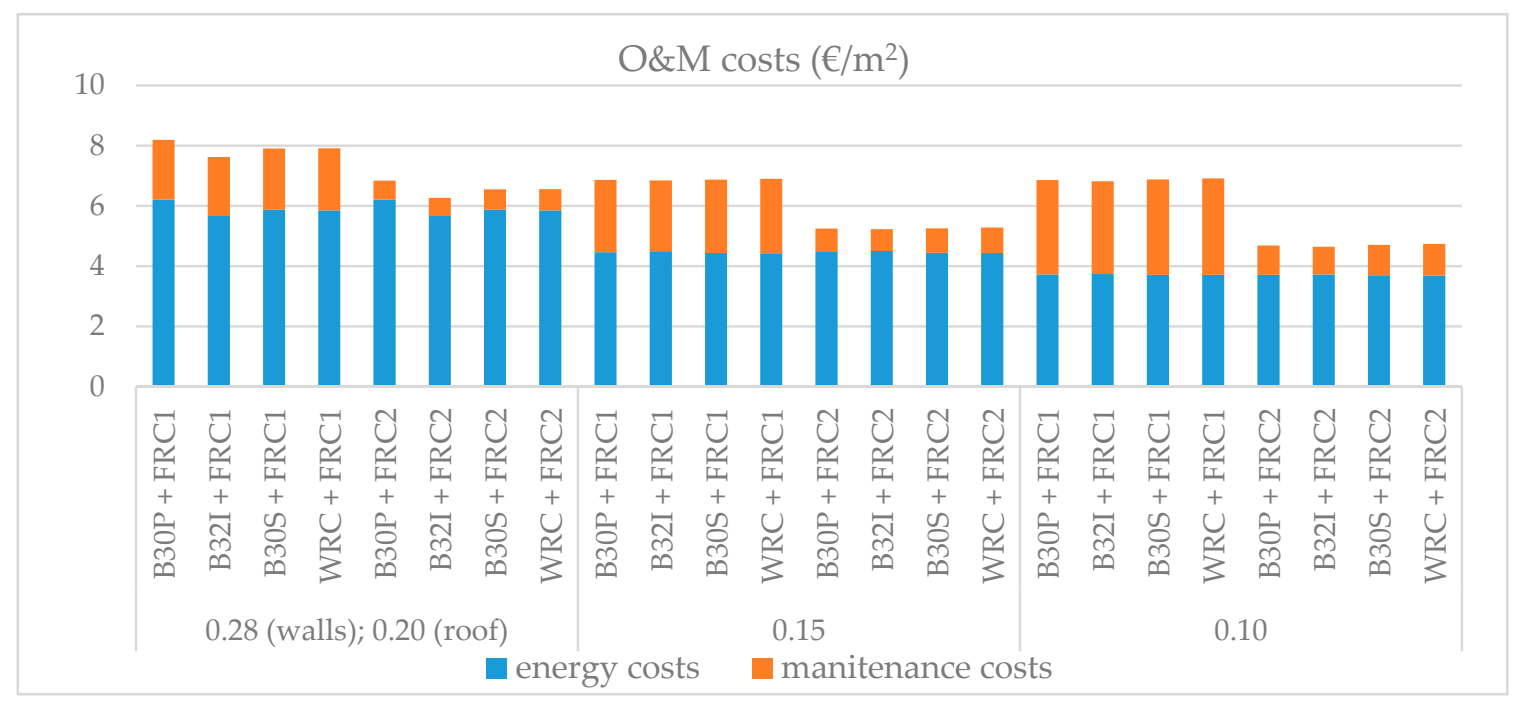

(b)

Figure 3. Cont. 


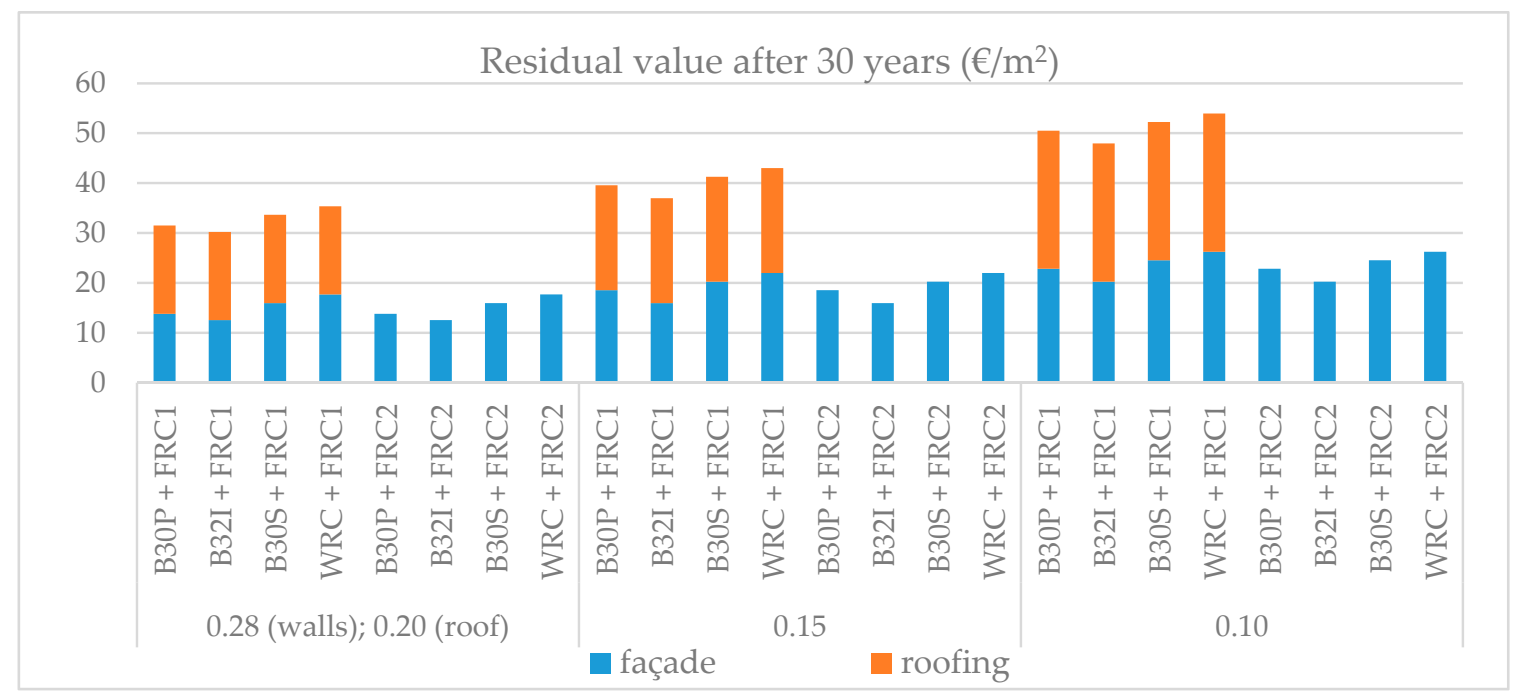

(c)

Figure 3. Comparison of life-cycle costs (LCC) for all variants: (a) initial investment costs; (b) operation and maintenance (O\&M) costs; (c) residual value.

Figure 3 shows the calculated initial investment costs, O\&M costs, and residual value for the exterior walls and flat roof by individual variants. Initial investment costs are divided into the cost for erecting all components for external walls and for the flat roof; annual O\&M costs are divided into energy costs for the space heating and cooling and maintenance costs for the façade and the roofing; the residual value is divided into the amount of the residual value for the façade and the roofing.

The economic assessment for each variant of building envelope components is performed by using the cost-optimal methodology and discounted to their equivalent present values based on the relevant discount factors [72,73]. Economic calculations are focused on a 30-year period, using the NPV method according to Equation (2) by using a discount rate of investment of $4 \%$. Table 4 summarizes the starting points of the economic calculation. The economic assessment is carried out below using advanced BIM approach and is implemented in the process of 5D BIM modelling. Thus, the results are presented in Section 3.7.

Table 4. Starting points of the economic assessment.

\begin{tabular}{ccc}
\hline Study Period & Years & $\mathbf{3 0}$ \\
\hline Service Life (façade/roofing FRC1/roofing FRC2) & Years & $40 / 20 / 30$ \\
Fraction of small repairs (in \%) (façade/FRC1/FRC2) & $\%$ & $20 / 30 / 25$ \\
Net heated floor area $\left(A_{h}\right)$ & $\mathrm{m}^{2}$ & 695.68 \\
Discount rate, $i$ & $\%$ & 4 \\
Energy price, Electricity & $€ / \mathrm{kWh}$ & 0.138 \\
\hline
\end{tabular}

\subsection{Advanced Use of the BIM Approach for Analysing LCC}

The advanced use of the BIM approach includes the use of the modern project management software that supports BIM such as Vico Office software [74], which allows the modelling of 4D BIM and 5D BIM. Using such a modern tool, the individual elements of the building, which are part of the 3D BIM, are directly linked to the information of time scheduling and cost estimation. These are so-called object models of structural elements given as a geometric image in a comprehensive 3D BIM. At the same time, process models can also be included for nonstructural elements and can therefore be called nonobject elements. These are, for example, energy costs and do not have a geometric image in 3D BIM. 
The process of performing LCC analysis in Vico Office is as follows: first, the created 3D BIM is imported into the module Model Register, followed by grouping of all individual elements of the 3D BIM according to the element type, and then merging the group of elements in the Takeoff Manager module. Figure 4 shows a group of all considered components of the external walls and flat roof elements (highlighted in yellow) with detailed information about each quantity (blue column).

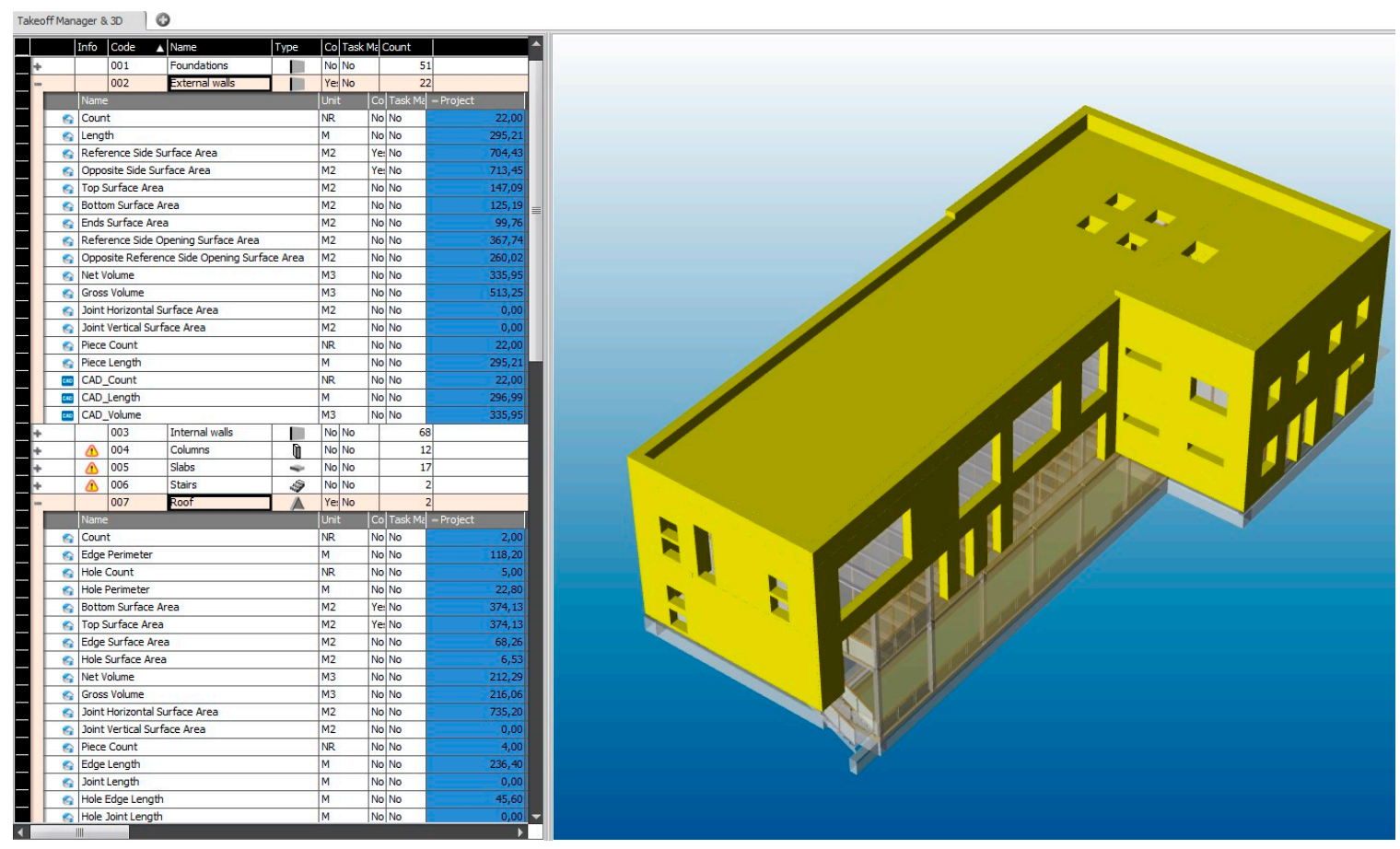

Figure 4. Group of external wall and flat roof elements with takeoff quantities in VO program.

The Cost Planner module provides a cost analysis for each variant of external wall and roof systems (described in Section 3.3). In addition, LCC is implemented in a structured way that includes (i) calculated initial investment costs for the execution of all components of the walls and the roof; (ii) the NPV of O\&M costs; (iii) the NPV of residual value. Initial investment costs in the Cost Planner module are calculated directly based on the connection to individual elements in the 3D BIM model with reference to source quantity. The economic evaluation of the NPV values of O\&M costs and residual value is, for now, carried out in external programs such as Excel and imported into VO unilaterally on the basis of guaranteed interoperability.

Figure 5, produced in the VO program's Cost Planner module, shows the structure for all elements of LCC for variant B30P + FRC2 (external wall with a brick system Porotherm 30 PROFI (B30P); and flat roof with reinforced concrete slab construction and polymeric waterproofing membrane for mechanically fixed roof (FRC2)), at $\mathrm{U}_{1}=0.15 \mathrm{~W} / \mathrm{m}^{2} \mathrm{~K}$ considered for exterior walls and flat roof. The detailed structure is presented only for calculation of initial construction costs for a masonry wall and a brick corner, showing the total normative quantities of labour and material (basic material and mechanization). The results of a cost analysis for each variant are given in Section 3.7. 


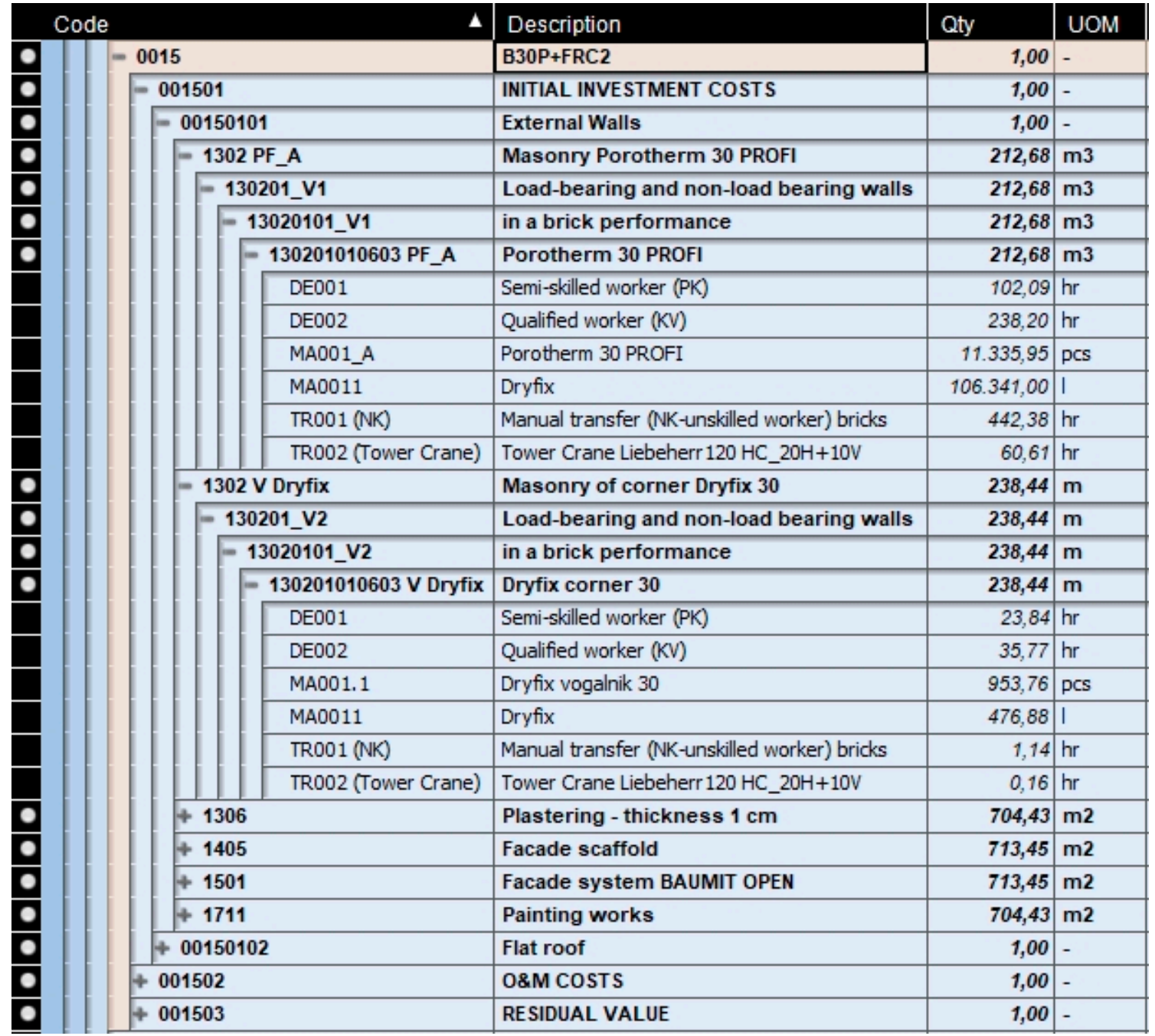

Figure 5. Structure for elements of LCC of variant B30P + FRC2 at $\mathrm{U}_{1}$ in VO program.

\subsection{Results of Cost Analysis}

The advanced use of the BIM approach elaborated 3D BIM for treated variants of the building envelope enable to calculate the lifetime costs. The costs analysis is utilized in the Cost Planner module of the VO program. Figure 6 shows the result of cost analysis within values of cumulative LCCs as evaluated for each variant and in detail by elements of LCCs for variant B30P + FRC2 at $\mathrm{U}_{1}$. Figure 7 gives a graphical representation of the bar charts for the results obtained for all variants distributed to calculated initial investment costs, NPV of O\&M costs, and the NPV of residual value at the end of the lifetime period. 


\begin{tabular}{|c|c|c|c|c|c|c|c|}
\hline \multicolumn{2}{|c|}{ Code } & \multirow{2}{*}{$\begin{array}{l}\text { Description } \\
\text { U0 }\end{array}$} & Base Cost & & & & \\
\hline 0 & -001 & & 0,00 & & & & \\
\hline$\bullet$ & +0011 & B30P+FRC1 & \begin{tabular}{ll|}
$\Delta$ & $233.191,91$
\end{tabular} & & & & \\
\hline 0 & +0012 & B321+FRC1 & $238.343,85$ & & & & \\
\hline 0 & +0013 & B30S+FRC1 & $\Delta \quad 232.712,23$ & & & & \\
\hline 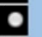 & +0014 & $W R C+F R C 1$ & \begin{tabular}{ll|}
$\Delta$ & $233.845,47$ \\
\end{tabular} & & & & \\
\hline 0 & +0015 & $B 30 P+F R C 2$ & $\Delta \quad 228.326,15$ & & & & \\
\hline 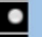 & +0016 & B321+FRC2 & $233.494,39$ & & & & \\
\hline 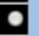 & +0017 & $B 30 \mathrm{~S}+\mathrm{FRC2}$ & $\begin{array}{l}\Delta \quad 227.862,77 \\
\end{array}$ & & & & \\
\hline$\overline{0}$ & +0018 & WRC+FRC2 & $\begin{array}{l}\Delta \quad 228.979,71 \\
\end{array}$ & & & & \\
\hline 으 & -002 & U1 & 0,00 & & & & \\
\hline 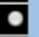 & +0011 & $B 30 P+F R C 1$ & $233.007,31$ & & & & \\
\hline 0 & +0012 & B321+FRC1 & $\Delta \quad 241.411,67$ & & & & \\
\hline 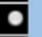 & +0013 & B30S+FRC1 & $\begin{array}{l}\Delta \quad 234.965,09 \\
\end{array}$ & & & & \\
\hline 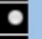 & +0014 & WRC+FRC1 & $\triangle \quad 236.326,60$ & & & & \\
\hline 윽 & +0015 & $\mathrm{~B} 30 \mathrm{P}+\mathrm{FRC2}$ & $\Delta \quad 225.608,35$ & & $\Delta$ & Description & Base Cost \\
\hline$\frac{\bullet}{6}$ & \begin{tabular}{|l|l}
+0016 \\
+0017
\end{tabular} & $\begin{array}{l}\mathrm{B} 321+\mathrm{FRC2} \\
\mathrm{B} 30 \mathrm{~S}+\mathrm{FRC2}\end{array}$ & 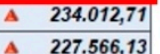 & 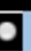 & -0015 & $\mathrm{~B} 30 \mathrm{P}+\mathrm{FRC2}$ & A $\quad 225.608,35$ \\
\hline 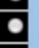 & +0018 & WRC+FRC2 & $\Delta \quad 228.911,34$ & $\underline{\underline{0}}$ & -001501 & INITIAL INVESTMENT COSTS & A $\quad 167.759,04$ \\
\hline 을 & -003 & U2 & 0,00 & 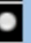 & +00150101 & External Walls & $96.599,52$ \\
\hline$\frac{0}{8}$ & \begin{tabular}{|l|}
+ \\
+0011 \\
0012
\end{tabular} & $\begin{array}{l}B 30 P+F R C 1 \\
B 321+F R C 1\end{array}$ & 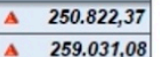 & 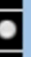 & +00150102 & Flat roof & $71.159,53$ \\
\hline 0 & $\begin{array}{l}+0012 \\
+0013\end{array}$ & $\begin{array}{l}\text { B321+FRC1 } \\
\text { B30S+FRC1 }\end{array}$ & 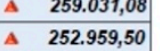 & e & -001502 & O\&M COSTS & $\begin{array}{ll}\Delta \quad 61.987,78\end{array}$ \\
\hline$\bullet$ & +0014 & WRC+FRC1 & $\Delta \quad 254.353,63$ & & 001102031113 & Energy costs & $52.844,56$ \\
\hline 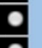 & +0015 & $\mathrm{~B} 30 \mathrm{P}+\mathrm{FRC2}$ & $\Delta \quad 239.591,71$ & & 001102031213 & Maintenance costs & $9.143,22$ \\
\hline 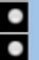 & \begin{tabular}{|l|}
+0016 \\
+0017
\end{tabular} & $\begin{array}{l}\text { B321+FRC2 } \\
B 30 S+F R C 2\end{array}$ & 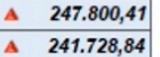 & 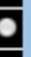 & -001503 & RESIDUAL VALUE & $-4.138,47$ \\
\hline & +0018 & WRC+FRC2 & $\Delta \quad 243.122,96$ & & 001503045 & Residual value - after 30 years & $-4.138,47$ \\
\hline
\end{tabular}

Figure 6. Results of a cost analysis in program $\mathrm{VO}$ for all variants and broken down by elements of LCC for variant B30P + FRC2 at $\mathrm{U}_{1}$.

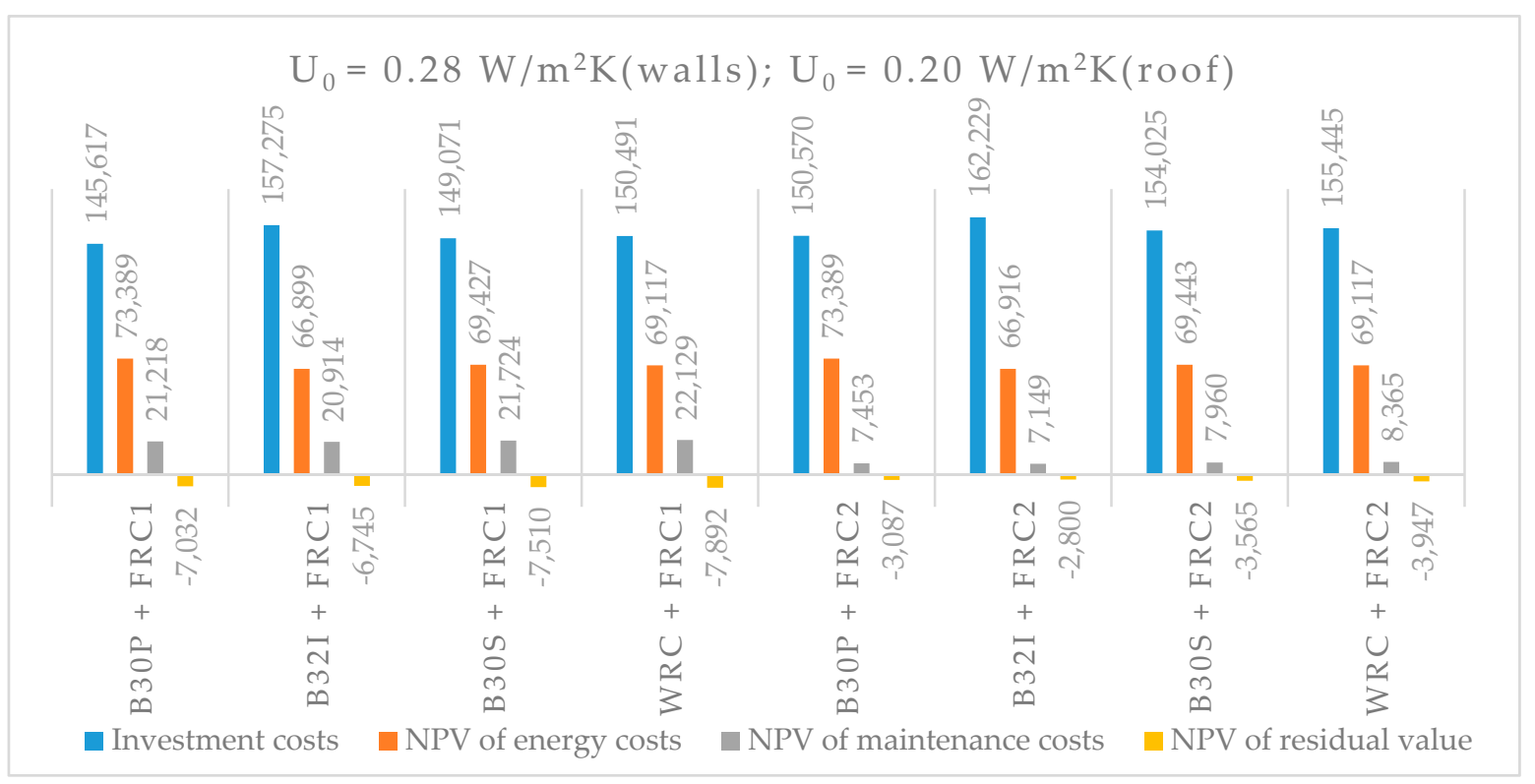

(a)

Figure 7. Cont. 


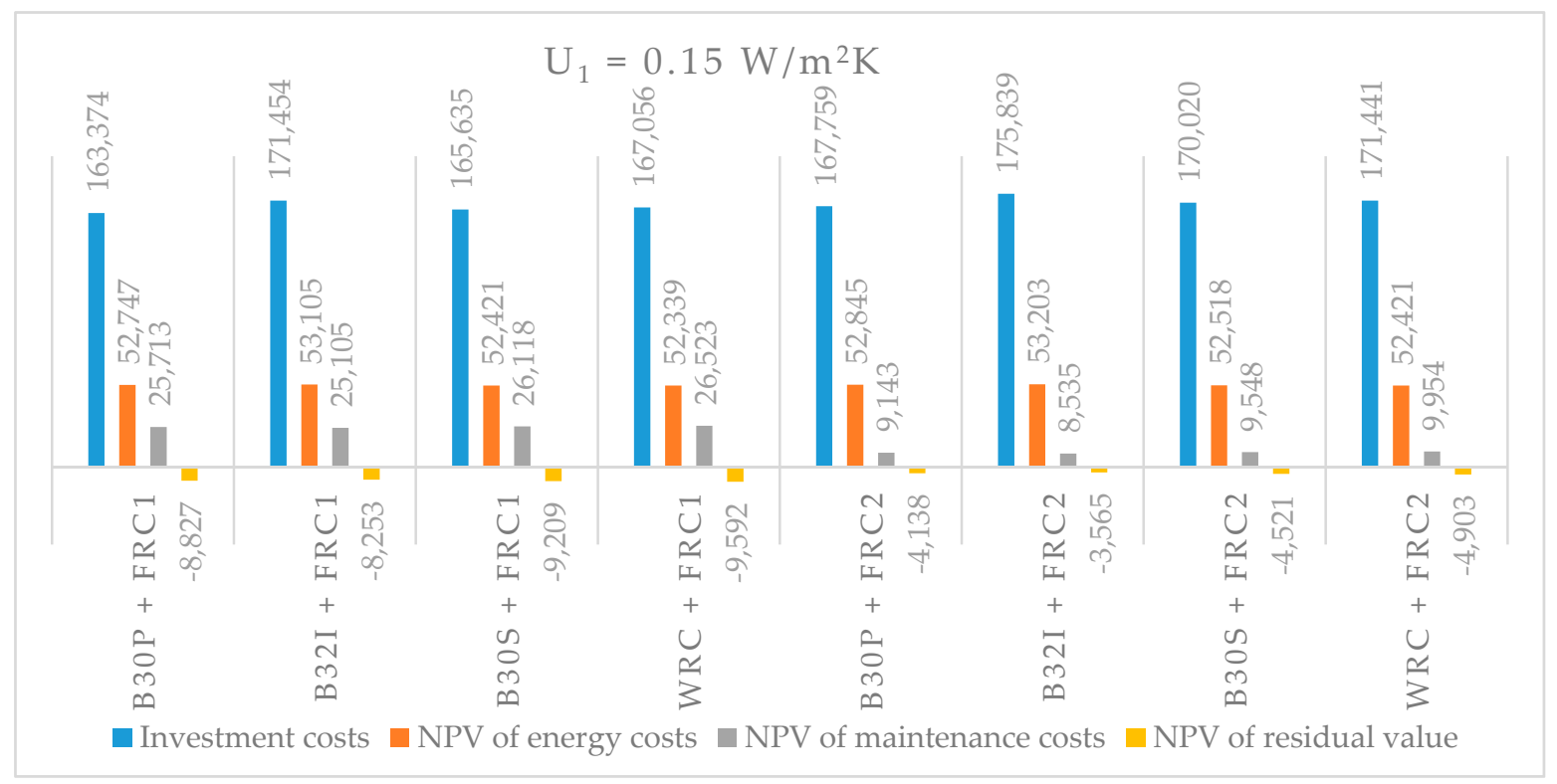

(b)

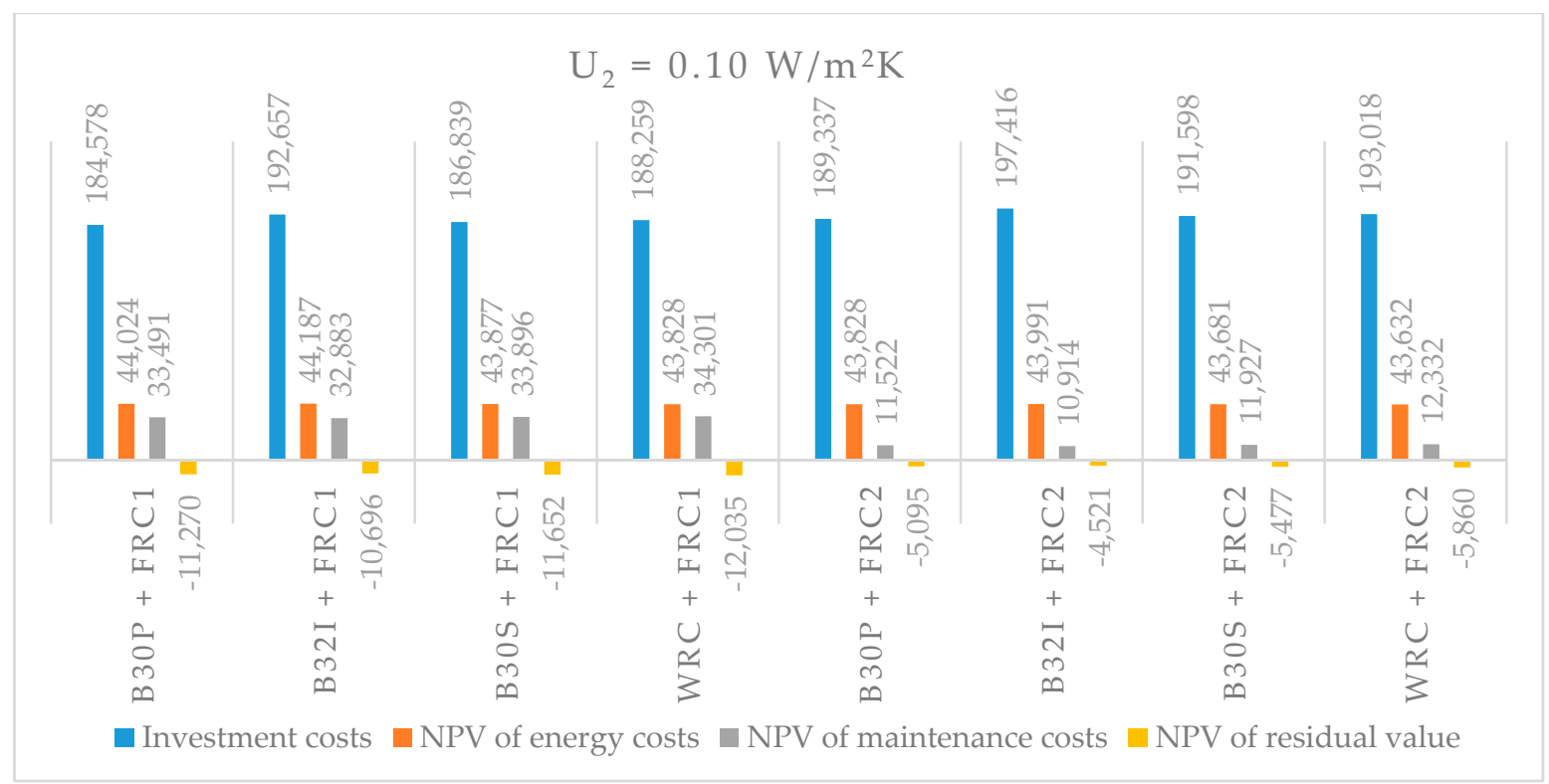

(c)

Figure 7. Results of a cost analysis broken down by elements of LCC for all variants: $(\mathbf{a})$ at $\mathrm{U}_{0} ;(\mathbf{b})$ at $\mathrm{U}_{1}$; (c) at $\mathrm{U}_{2}$.

\section{Discussion}

The results show that cumulative LCC are the lowest for the variant B30P + FRC2 at $\mathrm{U}_{1}$ and total $225,608.35 €$, where the initial investment costs total $167,759.05 €$, the NPV of O\&M cost for used energy (heating and cooling) and for maintaining envelope components in the lifetime period totals $61,987.78 €$, and the NPV of residual value is $4138.47 €$ (reducing the cumulative LCC value). If all other costs for construction of the building $(665,504.42 €$, see Section 3.5) are added to initial investment costs for installation of wall and roof components according to the lowest variant B30P + FRC2, the total investment value of the building would be $777,771.71 €$.

Further, if variants are considered by individual level of thermal transmittance, the variant B30P + FRC2 has the lowest cumulative LCC also at $\mathrm{U}_{2}$, whereas slightly lower LCC at $\mathrm{U}_{0}$ is achieved 
by the variant B30S + FRC2, but only for $0.2 \%$. The main reason for this lies in the performance of flat roofing in the FRC2 system. Namely, LCC of this variant have, due to the FRC1 system roof, low maintenance costs (e.g., these costs are annually lower by $36 \%$ at $\mathrm{U}_{1}$; what is more, the roof does not need to be changed in its 30-year life period) and by the end of the lifetime period of this element the value is zero. However, initial construction costs for FRC2 are higher, for example, by $15 \%$ at $U_{1}$. If only initial investments costs are taken into account, the lowest value is reached by the variant $\mathrm{B} 30 \mathrm{P}+\mathrm{FRC1}$ at $\mathrm{U}_{0}$, due to the lower $\mathrm{U}$-value. This wall system requires only $3 \mathrm{~cm}$ thermal insulation for variant B30P, while $8 \mathrm{~cm}$ is needed for variant B30S and even $12 \mathrm{~cm}$ for WRC. Even though the variant B32I does not require thermal insulation, the price of the bricks is much higher. Considering the roof system for the variant FRC1, investment expenses for multilayer waterproofing strips are lower than in performance of the variant FRC2 with polymeric waterproofing membrane. However, variant B30P + FRC1 does not have a favourable value of cumulative LCC due to the high costs for heating and cooling and maintenance of external walls and the roof.

Figure 8 shows a bar chart for difference in cumulative LCC for all combinations of wall and roof systems at each level of $U$-value according to baseline variant. The baseline variant is considered as the actually performed variant for external walls made of brick Porotherm $30 \mathrm{~S}$ Plus and the flat roof FRC1 with roofing from waterproofing strips, i.e., the combination B30S + FRC1.

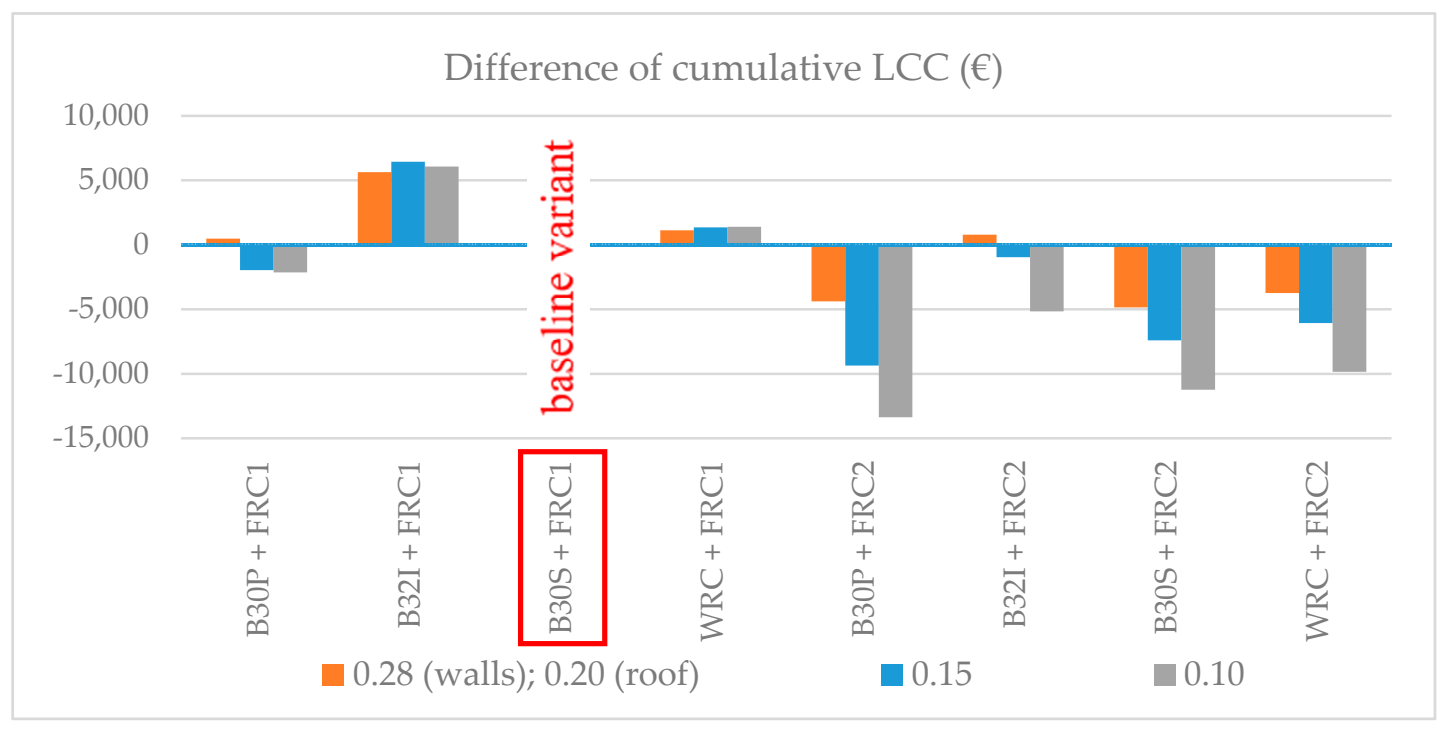

Figure 8. Difference of cumulative LCC according to baseline variant.

Results of the cost analysis suggest that the lowest cumulative LCC (B30P + FRC2) is comparable to the variant B30S + FRC2 at all levels of U-value. The variants B32I + RC1 and B32I + RC2 in all U-values deviate the most due to the high price of the bricks. However, LCCs of all variants which include roof FRC2 are lower than variants with the roof FRC1 due to the lower operating costs, which do not include the costs for reinvestment components for roofing in the variants for FRC2, so the residual value also equals zero, even though the initial investment costs for FRC2 are higher for $6.57 \%$ (valid at $\mathrm{U}_{1}$; relative value). Furthermore, the comparison of cumulative LCC for the variant B30P + FRC2 between $\mathrm{U}$-values shows that the difference to $\mathrm{U}_{0}$ is $2717.78 €$ and to $\mathrm{U}_{2}$ is $13,983.34 €$. In order to achieve the $\mathrm{U}_{2}$ level, the cumulative LCC are higher by $6.20 \%$, namely the costs of the wall and roof system components installation are higher by $12.86 \%$, the costs for the energy are lower by $17.06 \%$, costs for maintenance are higher by $26.01 \%$, and residual value is higher by $23.1 \%$ (the percentages are given as relative values).

The cheaper construction of roofing in FRC1 variants leads to the initial investment costs being in general lower for all U-values; however, further substantial differences between variants of each wall structural system originate in the varying prices of bricks (the difference at $U_{1}$ between the cheapest 
variant B30P and the most expensive B32I is 13.97\%). The energy costs (as a part of O\&M costs) between all variants and within each U-value do not differ significantly due to the predefined U-value of all envelope components. Greater deviation can be noticed only in variants with Porotherm 32 IZO PROFI bricks at $\mathrm{U}_{0}$, because this value can be reached already without thermal isolation, so the $\mathrm{U}_{\text {actual }}$ is lower as defined. However, maintenance costs change depending on the layers of envelope components. The calculation thus considers different finishing layers of external walls and roof systems, which affect maintenance costs in terms of the life span of façade and roofing. As a result, the maintenance costs for the façade do not differ much within each $U$-value, but they are characteristically different for roofing in its total 30-year period. For example, at $U_{1}$ for variants with FRC2 (the life span is 30 years; the share of the new value is $25 \%$ ) with regard to the variants with FRC1 (the life span is 20 years; the share of the new value is 30\%) the NPV of maintenance costs is lower by $77.69 \%$, because this calculation also considers maintenance costs in roofing with FRC1, namely, in year 20. Consequently, the lifetime period impacts residual values which are lower in variants with roofing FRC2.

According to the discussed findings, variation or change of the used materials and layer thickness of envelope components can influence the energy performance indicators and the LCC values of each envelope component. In doing so, using the BIM approach provides useful and modern support for the cost calculation. Therefore, the implemented calculation, performed with the help of the 5D BIM modelling method, can collect all data in one place, accessible to all participants, and calculations of elements of LCC for each variant can be performed rapidly. The usage of the modern database-supported BIM project management software provides access to various price lists and technical data of resources, which can be changed dynamically by individual suppliers, subcontractors, etc. Therefore, the input of the newest data into the implemented 5D BIM allows for the automatic update of all treated costs and can thus be used as relevant input data for the calculation. What is more, the update of recalculation of the initial investment costs for the changes made to the input data in the 3D BIM, e.g., element geometry or used materials, is carried out automatically. Consequently, NPV values of O\&M costs and residual value are changed with the help of the links in external programs. The implementation of the suggested systematic approach provides investors with the opportunity to make energy- and cost-effective decisions about building envelope components already in the earliest design phases.

\section{Conclusions}

The investors' decision about the choice of building envelope components, when they follow the principle of sustainable building, is related to selection of the cost-effective variant; however, designing a new building allows for several key components of building, whose choice impacts the energy and cost efficiency of the building. For this reason, our study proposes the new approach for systematic performance of the energy and cost analysis of building envelope components by using the BIM approach. The approach enables automated/semiautomated comprehensive analysis and represents a contribution to advanced construction project management as a sophisticated method for the environmental assessment of building envelope components throughout the life cycle by simultaneous inclusion of economic valuation. Compared to other studies, our approach provides a simple overview of all costs in the life cycle of the building and could be utilized for both new constructions and renovation of existing ones.

The applicability of the proposed approach was tested on a new preschool building in the city of Maribor. Our case study determines two different structural systems of external wall, i.e. brick (three alternatives) and reinforced concrete (one alternative), and two roof systems. Three different $\mathrm{U}$-values were analysed for each variant, meaning that the thickness of the used thermal isolation of walls and roof vary. All variants were initially modelled as 3D BIM (Arhicad), and then, based on 3D BIM, performed in relevant programs for energy (DesignBuilder) and cost analysis (Vico Office). The cost analysis was based on the LCC approach, while the economic assessment of selected envelope components was performed through their NPV and in accordance with cost-optimal methodology. The results reveal that variant $\mathrm{B} 30 \mathrm{P}+\mathrm{FRC} 2$ at $\mathrm{U}_{1}$ has the lowest cumulative LCC. At the same time, 
the variant $\mathrm{B} 32 \mathrm{I}+\mathrm{FRC1}$ at $\mathrm{U}_{2}$ is least cost efficient due to the high brick price and high maintenance costs over a 30-year period.

The usage of evaluation approach for energy and cost effectiveness implementing BIM, which is becoming the standard in the AECO industry, is expected to be useful in decision-making at an early design stage. In this way, the investors have comprehensive insight into all costs referring to building envelope, that arise during the building lifetime. Moreover, calculation of initial investment costs in BIM project management software VO, using the Cost Planner module, presents a 5D BIM modelling approach. This means that the recalculation of initial investment costs for object models of structural elements is conducted sophistically with automatic and semiautomatic update of NPV values for other costs that arise in the lifespan; in this way, all information is collected in one place and is thus interconnected. Based on the gained results, the investor can make the right decision about the energy- and cost-effective variant with a contemporary and fast method for comparing various variants. In addition, the presented approach can be implemented to other building envelope components as well as for new or existing buildings, and with comparable economic environments.

Our further research will focus on the study of the interoperability of the implemented software for individual professional treatment according to the workflow presented in Figure 1. The study will aim to optimize the process of information transmission and automation aggregation, which serves for the comprehensive treatment of construction projects with the BIM approach. In terms of building design (such as changes in orientation and the percentage of holes) and influencing energy and cost planning, it will address the effects of other parameters that have impact on efficiency of variant solutions and sensitivity to parameter changes.

Author Contributions: Conceptualization, Z.P. and N.Š.; methodology, Z.P., D.M. and N.Š.; validation, formal analysis, Z.P., D.M. and N.Š.; writing—original draft preparation, N.Š.; resources, Z.P. and N.Š.; data curation, Z.P. and N.S..; writing—review and editing, Z.P. and N.Š.; visualization, Z.P. All authors have read and agreed to the published version of the manuscript.

Acknowledgments: This research was supported by the company ENERGO-MAKS d.o.o. through Cooperation Agreement No. 02/2017-NŠ-DDP “Research and Development Project for operational monitoring of construction with BIM approach". Our thanks also go to EnergaP-Energy Agency of Podravje for data provision and the Wienerberger company for a donation.

Conflicts of Interest: The authors declare no conflict of interest.

\section{References}

1. Energy Statistics 2017. Eurostat, EU Commission, DG ENER, Unit A4. Available online: http://ec.europa.eu/ energy/en/data-analysis/country (accessed on 15 May 2020).

2. @WorldGBC. World's Largest Collaborative Retrofit Project Launches to Cut Emissions from Buildings|World Green Building Council. Available online: https:/www.worldgbc.org/ (accessed on 15 May 2020).

3. Economidou, M.; Atanasiu, B.; Despret, C.; Maio, J.; Nolte, I.; Rapf, O. Europe's Buildings under the Microscope. A Country-by-Country Review of the Energy Performance of Buildings; Buildings Performance Institute Europe (BPIE): Brussels, Belgium, 2011; p. 132.

4. Directive 2002/91/EC of the European Parliament and of the Council of 16 December 2002 on the Energy Performance of Buildings. Available online: https://eur-lex.europa.eu/LexUriServ/LexUriServ.do?uri=OJ:L: 2003:001:0065:0071:EN:PDF (accessed on 15 May 2020).

5. Directive 2010/31/EU of the European Parliament and of the Council of 19 May 2010 on the Energy Performance of Buildings. Available online: https://eur-lex.europa.eu/legal-content/EN/TXT/PDF/?uri= CELEX:32010L0031\&from=EN (accessed on 15 May 2020).

6. Feng, G.; Dou, B.; Xu, X.; Chi, D.; Sun, Y.; Hou, P. Research on Energy Efficiency Design Key Parameters of Envelope for Nearly Zero Energy Buildings in Cold Area. Procedia Eng. 2017, 205, 686-693. [CrossRef]

7. Evin, D.; Ucar, A. Energy impact and eco-efficiency of the envelope insulation in residential buildings in Turkey. Appl. Therm. Eng. 2019, 154, 573-584. [CrossRef]

8. Dodoo, A.; Gustavsson, L.; Tettey, U.Y. Cost-optimized energy-efficient building envelope measures for a multi-storey residential building in a cold climate. Energy Procedia 2019, 158, 3760-3767. [CrossRef] 
9. Ascione, F.; Bianco, N.; Mauro, G.M.; Napolitano, D.F. Building envelope design: Multi-objective optimization to minimize energy consumption, global cost and thermal discomfort. Application to different Italian climatic zones. Energy 2019, 174, 359-374. [CrossRef]

10. Ascione, F.; Bianco, N.; De Masi, R.F.; De Stasio, C.; Mauro, G.M.; Vanoli, G.P. Multi-objective optimization of the renewable energy mix for a building. Appl. Therm. Eng. 2016, 101, 612-621. [CrossRef]

11. Gercek, M.; Arsan, Z.D. Energy and environmental performance based decision support process for early design stages of residential buildings under climate change. Sustain. Cities Soc. 2019, 48, 101580. [CrossRef]

12. Bano, F.; Sehgal, V. Evaluation of energy-efficient design strategies: Comparison of the thermal performance of energy-efficient office buildings in composite climate, India. Sol. Energy 2018, 176, 506-519. [CrossRef]

13. Sozer, H. Improving energy efficiency through the design of the building envelope. Build. Environ. 2010, 45, 2581-2593. [CrossRef]

14. Šuman, N.; Žigart, M.; Premrov, M.; Leskovar, V. Žegarac Approach to Refurbishment of Timber Preschool Buildings with a View on Energy and Economic Efficiency. J. Civ. Eng. Manag. 2019, 25, 27-40. [CrossRef]

15. Lin, Y.-H.; Tsai, K.-T.; Lin, M.-D.; Yang, M.-D. Design optimization of office building envelope configurations for energy conservation. Appl. Energy 2016, 171, 336-346. [CrossRef]

16. Krstic-Furundzic, A.; Vujosevic, M.; Petrovski, A. Energy and environmental performance of the office building facade scenarios. Energy 2019, 183, 437-447. [CrossRef]

17. Kovacic, I.; Waltenbereger, L.; Gourlis, G. Tool for life cycle analysis of facade-systems for industrial buildings. J. Clean. Prod. 2016, 130, 260-272. [CrossRef]

18. Zhou, J.; Nazi, W.I.W.M.; Wang, Y.; Roskilly, A. Investigating the impact of building's facade on the building's energy performance-A case study. Energy Procedia 2019, 158, 3144-3151. [CrossRef]

19. Loukaidou, K.; Michopoulos, A.; Zachariadis, T. Nearly-zero Energy Buildings: Cost-optimal Analysis of Building Envelope Characteristics. Procedia Environ. Sci. 2017, 38, 20-27. [CrossRef]

20. Hamdy, M.; Siren, K.; Attia, S. Impact of financial assumptions on the cost optimality towards nearly zero energy buildings-A case study. Energy Build. 2017, 153, 421-438. [CrossRef]

21. Aelenei, L.; Paduos, S.; Petran, H.; Tarres, J.; Ferreira, A.R.; Corrado, V.; Camelo, S.; Polychroni, E.; Sfakianaki, K.; Goncalves, H.; et al. Implementing Cost-optimal Methodology in Existing Public Buildings. Energy Procedia 2015, 78, 2022-2027. [CrossRef]

22. Morrissey, J.; Horne, R. Life cycle cost implications of energy efficiency measures in new residential buildings. Energy Build. 2011, 43, 915-924. [CrossRef]

23. La Fleur, L.; Rohdin, P.; Moshfegh, B. Investigating cost-optimal energy renovation of a multifamily building in Sweden. Energy Build. 2019, 203, 109438. [CrossRef]

24. Gustafsson, M.S.; Myhren, J.A.; Dotzauer, E.; Gustafsson, M. Life Cycle Cost of Building Energy Renovation Measures, Considering Future Energy Production Scenarios. Energies 2019, 12, 2719. [CrossRef]

25. Kneifel, J. Life-cycle carbon and cost analysis of energy efficiency measures in new commercial buildings. Energy Build. 2010, 42, 333-340. [CrossRef]

26. Han, G.; Srebric, J.; Enache-Pommer, E. Variability of optimal solutions for building components based on comprehensive life cycle cost analysis. Energy Build. 2014, 79, 223-231. [CrossRef]

27. Morrissey, J.; Meyrick, B.; Sivaraman, D.; Horne, R.; Berry, M. Cost-benefit assessment of energy efficiency investments: Accounting for future resources, savings and risks in the Australian residential sector. Energy Policy 2013, 54, 148-159. [CrossRef]

28. Maučec, D. The Analysis of a Sustainable Renovation of a Multi-Dwelling Building in Dominkuševa Street in Maribor. Master's Thesis, University of Maribor, Maribor, Slovenia, 2016. (In Slovenian). Available online: https://dk.um.si/IzpisGradiva.php?id=62872\&lang=eng\&prip=rul:1727139:d2 (accessed on 15 May 2020).

29. Završki, J. BIM for Sustainable Design and Energy Efficiency Improvements. Graduation Thesis, University of Ljubljana, Ljubljana, Slovenia, 2014. (In Slovenian). Available online: https://repozitorij.uni-lj.si/IzpisGradiva. php?id=32346\&lang=eng\&prip=dkum:8730174:d4 (accessed on 15 May 2020).

30. Pavličič, A. Use of the Vico Office Software for the 4D and 5D Information Modeling for Building External Walls of the Residential Object in Ljutomer. Master's Thesis, University of Maribor, Maribor, Slovenia, 2016. (In Slovenian). Available online: https://dk.um.si/IzpisGradiva.php?id=59450\&lang=eng (accessed on 15 May 2020).

31. Jin, R.; Zhong, B.; Ma, L.; Hashemi, A.; Ding, L. Integrating BIM with building performance analysis in project life-cycle. Autom. Constr. 2019, 106, 102861. [CrossRef] 
32. Asatani, K.; Takeda, H.; Yamano, H.; Sakata, I. Scientific Attention to Sustainability and SDGs: Meta-Analysis of Academic Papers. Energies 2020, 13, 975. [CrossRef]

33. Kamel, E.; Memari, A.M. Review of BIM's application in energy simulation: Tools, issues, and solutions. Autom. Constr. 2019, 97, 164-180. [CrossRef]

34. Azhar, S.; Brown, J.W.; Sattineni, A. A Case Study of Building Performance Analyses Using Building Information Modeling. In Proceedings of the 27th International Symposium on Automation and Robotics in Construction, International Association for Automation and Robotics in Construction (IAARC), Bratislava, Slovakia, 24-27 June 2010; pp. 213-222.

35. Guo, S.-J.; Wei, T. Cost-effective energy saving measures based on BIM technology: Case study at National Taiwan University. Energy Build. 2016, 127, 433-441. [CrossRef]

36. Natephra, W.; Yabuki, N.; Fukuda, T. Optimizing the evaluation of building envelope design for thermal performance using a BIM-based overall thermal transfer value calculation. Build. Environ. 2018, 136, 128-145. [CrossRef]

37. Santos, R.; Costa, A.A.; Silvestre, J.D. Integration of LCA and LCC analysis within a BIM-based environment. Autom. Constr. 2019, 103, 127-149. [CrossRef]

38. Santos, R.; Costa, A.A.; Silvestre, J.D.; Vandenbergh, T. BIM-based life cycle assessment and life cycle costing of an office building in Western Europe. Build. Environ. 2020, 169, 106568. [CrossRef]

39. Shadram, F.; Johansson, T.; Lu, W.; Schade, J.; Olofsson, T. An integrated BIM-based framework for minimizing embodied energy during building design. Energy Build. 2016, 128, 592-604. [CrossRef]

40. Kim, J.-U.; Hadadi, O.A.; Kim, H.; Kim, J. Development of A BIM-Based Maintenance Decision-Making Framework for the Optimization between Energy Efficiency and Investment Costs. Sustainability 2018, 10, 2480. [CrossRef]

41. Jrade, A.; Jalaei, F. Integrating building information modelling with sustainability to design building projects at the conceptual stage. Build. Simul. 2013, 6, 429-444. [CrossRef]

42. Marzouk, M.; Azab, S.; Metawie, M. BIM-based approach for optimizing life cycle costs of sustainable buildings. J. Clean. Prod. 2018, 188, 217-226. [CrossRef]

43. Cavalliere, C.; Habert, G.; Dell'Osso, G.R.; Hollberg, A. Continuous BIM-based assessment of embodied environmental impacts throughout the design process. J. Clean. Prod. 2019, 211, 941-952. [CrossRef]

44. Šuman, N.; Pučko, Z. Integration of Industry 4.0 for Advanced Construction Project Management. In Advances in Business Information Systems and Analytics; IGI Global: Hershey, PA, USA, 2020; pp. 533-567.

45. BIM Levels Explained|NBS. Available online: https://www.thenbs.com/knowledge/bim-levels-explained (accessed on 15 May 2020).

46. LOD|BIMForum. Available online: https://bimforum.agc.org/lod/ (accessed on 15 May 2020).

47. BIM Dimensions-3D, 4D , 5D, 6D , 7D BIM Explained. Available online: http://biblus.accasoftware.com/en/ bim-dimensions-3d-4d-5d-6d-7d-bim-explained/ (accessed on 15 May 2020).

48. Pučko, Z.; Vincek, D.; Štrukelj, A.; Šuman, N. Application of 6D Building Information Model (6D BIM) for Business-storage Building in Slovenia. In Proceedings of the IOP Conference Series: Materials Science and Engineering, Prague, Czech Republic, 12-16 June 2017; Volume 245. [CrossRef]

49. ISO-ISO 15686-5:2017-Buildings and Constructed Assets—Service Life Planning-Part 5: Life-Cycle Costing. Available online: https://www.iso.org/standard/61148.html (accessed on 15 May 2020).

50. Guidelines Accompanying Commission Delegated Regulation (EU) No 244/2012 of 16 January 2012 Supplementing Directive 2010/31/EU of the European Parliament and of the Council on the Energy Performance of Buildings by Establishing a Comparative Methodology Framework for Calculating Cost-Optimal Levels of Minimum Energy Performance Requirements for Buildings and Building Elements. Available online: http://eur-lex.europa.eu/LexUriServ/LexUriServ.do?uri=OJ:L:2012:081:0018:0036:en:PDF (accessed on 15 May 2020).

51. Patiño-Cambeiro, F.; Armesto, J.; Bastos, G.; Prieto-López, J.I.; Barbeito, F.P. Economic appraisal of energy efficiency renovations in tertiary buildings. Sustain. Cities Soc. 2019, 47, 101503. [CrossRef]

52. Kindergarten Studenci Maribor-Unit Pekre, Basic Design, Elelectronic File, No. 120-44-58-10; Projekta Inženiring Ptuj d.o.o: Ptuj, Slovenia, 2011. (In Slovenian)

53. Technical Guidelines TSG-1-004:2010 Efficient use of Energy. 2010. (In Slovenian). Available online: http://www.arhiv.mop.gov.si/fileadmin/mop.gov.si/pageuploads/zakonodaja/prostor/graditev/TSG01-004_2010.pdf (accessed on 15 May 2020). 
54. Porotherm 30 Profi. Available online: https://www.wienerberger.si/proizvodi/zid/porotherm-opeka/ porotherm-30-profi.html (accessed on 15 May 2020).

55. Porotherm 32 IZO Profi. Available online: https://www.wienerberger.si/proizvodi/zid/porotherm-opeka/ porotherm-32-izo-profi.html (accessed on 15 May 2020).

56. Porotherm $30 \mathrm{~S}$ Plus. Available online: https://www.wienerberger.si/proizvodi/zid/porotherm-opeka/ porotherm-30-s-plus.html (accessed on 15 May 2020).

57. DesignBuilder Software Ltd-Home. Available online: https://designbuilder.co.uk/ (accessed on 15 May 2020).

58. Compact Ventilation Unit LG 3200; J. PICHLER Gesellschaft m.b.H.: Klagenfurt am Wörthersee, Austria, 2020; p. 16.

59. Passive House Institute. Available online: https://passivehouse.com/ (accessed on 15 May 2020).

60. Rules on the Ventilation and Air-Conditioning of Buildings. Official Gazette of the Republic of Slovenia No. 42/02, 105/02, 110/02, 61/17. (In Slovenian). Available online: http://www.pisrs.si/Pis.web/ pregledPredpisa?id=PRAV4223 (accessed on 15 May 2020).

61. Norms for Construction Works; Chamber of Craft and Small Business of Slovenia, Construction Section: Ljubljana, Slovenia, 2005. (In Slovenian)

62. Wooden Formwork-Doka. Available online: https://www.doka.com/si/index (accessed on 15 May 2020).

63. Indeksi za Obračun Razlike v Ceni Gradbenih Storitev; Chamber of Commerce and Industry of Slovenia (CCIS): Ljubljana, Slovenia, 2018. (In Slovenian)

64. Price for Construction Materials. Available online: https://www.merkur.si/gradnja/ (accessed on 15 May 2020).

65. Wienerberger-Price List 2018. Available online: https://njegac.si/2018/01/08/cenik-izdelkov-proizvajalcawienerberger-in-tondach-za-leto-2018/ (accessed on 15 May 2020).

66. Baumit-Price list 2020. Available online: https://baumit.si/files/si/prospekti/Cenik.pdf (accessed on 15 May 2020).

67. Knauf Insulation-Price List 2020. Available online: https://www.knaufinsulation.si/sites/ki_si/files/images/ KI-CENIK\%202019.pdf (accessed on 15 May 2020).

68. Fragmat-Price List 2019. Available online: http://www.fragmat.si/si/gradbeni-program/novice/2019/02/77Ceniki-2019 (accessed on 15 May 2020).

69. Šuman, N.; Pučko, Z. Final Report on the Results of the R \& D Project Operational Monitoring of the Construction with the BIM Approach, Faculty of Civil Engineering, Transportation Engineering and Architecture; University of Maribor: Maribor, Slovenia, 2017. (In Slovenian)

70. Rules on Standards for the Maintenance of Apartment Buildings and Apartments. Official Gazette of the Republic of Slovenia No. 20/2004, 18/2011. (In Slovenian). Available online: http://www.pisrs.si/Pis.web/ pregledPredpisa?id=PRAV5263 (accessed on 15 May 2020).

71. Sika Deutschland GmbH-Environmental Product Declaration; Institut Bauen und Umwelt e.V. (IBU): Berlin, Germany, 2015.

72. Rushing, A.S.; Kneifel, J.D.; Lippiatt, B.C. Energy Price Indices and Discount Factors for Life-Cycle Cost Analysis-2010 Federal Energy Management Program; NISTIR 85-3273-23 Rev. 5/08; National Institute of Standards and Technology (NIST): Gaithersburg, MD, USA, 2015; p. 65.

73. Bonakdar, F.; Dodoo, A.; Gustavsson, L. Cost-optimum analysis of building fabric renovation in a Swedish multi-story residential building. Energy Build. 2014, 84, 662-673. [CrossRef]

74. BIM Solutions|General Contractor Solutions. Available online: https:/gc.trimble.com/product-categories/ bim-solutions (accessed on 15 May 2020).

(C) 2020 by the authors. Licensee MDPI, Basel, Switzerland. This article is an open access article distributed under the terms and conditions of the Creative Commons Attribution (CC BY) license (http://creativecommons.org/licenses/by/4.0/). 